\title{
Lessons learned from the monitoring of turbidity currents and guidance for future platform designs
}

\author{
Michael Clare ${ }^{1 *}$, D. Gwyn Lintern², Kurt Rosenberger ${ }^{3}$, \\ John E. Hughes Clarke ${ }^{4}$, Charles Paull ${ }^{5}$, Roberto Gwiazda ${ }^{5}$, \\ Matthieu J. B. Cartigny ${ }^{6}$, Peter J. Talling ${ }^{6}$, Daniel Perara ${ }^{7}$, Jingping $\mathrm{Xu}^{8}$, \\ Daniel Parsons 9 , Ricardo Silva Jacinto ${ }^{10}$ and Ronan Apprioual ${ }^{10}$ \\ ${ }^{1}$ National Oceanography Centre, European Way, Southampton SO14 3ZH, UK \\ ${ }^{2}$ Geological Survey of Canada, Institute of Ocean Science, Canada \\ ${ }^{3}$ United States Geologic Survey, Santa Cruz, USA \\ ${ }^{4}$ Center for Coastal and Ocean Mapping/Joint Hydrographic Center, New Hampshire, \\ USA \\ ${ }^{5}$ Monterey Bay Aquarium Research Institute, Moss Landing, USA \\ ${ }^{6}$ Departments of Earth Sciences and Geography, Durham, UK \\ ${ }^{7}$ Canadian Coast Guard, Victoria, BC V8V 4V9, Canada \\ ${ }^{8}$ Southern University of Science and Technology, Shenzhen, China \\ ${ }^{9}$ Energy and Environment Institute, University of Hull, Cottingham Road, \\ Hull HU6 7RX, UK \\ ${ }^{10}$ Marine Geosciences Unit, IFREMER, Centre de Brest, CS10070, 29280 Plouzané, \\ France \\ (D) DGL, 0000-0003-1057-2670; KR, 0000-0002-5185-5776; \\ JEHC, 0000-0002-3846-9926; RG, 0000-0002-1144-3865; MJBC, 0000-0001-6446-5577 \\ *Correspondence: m.clare@noc.ac.uk
}

\begin{abstract}
Turbidity currents transport globally significant volumes of sediment and organic carbon into the deep-sea and pose a hazard to critical infrastructure. Despite advances in technology, their powerful nature often damages expensive instruments placed in their path. These challenges mean that turbidity currents have only been measured in a few locations worldwide, in relatively shallow water depths $(<<2 \mathrm{~km})$. Here, we share lessons from recent field deployments about how to design the platforms on which instruments are deployed. First, we show how monitoring platforms have been affected by turbidity currents including instability, displacement, tumbling and damage. Second, we relate these issues to specifics of the platform design, such as exposure of large surface area instruments within a flow and inadequate anchoring or seafloor support. Third, we provide recommended modifications to improve design by simplifying mooring configurations, minimizing surface area and enhancing seafloor stability. Finally, we highlight novel multi-point moorings that avoid interaction between the instruments and the flow, and flow-resilient seafloor platforms with innovative engineering design features, such as feet and ballast that can be ejected. Our experience will provide guidance for future deployments, so that more detailed insights can be provided into turbidity current behaviour, in a wider range of settings.
\end{abstract}

Reports of sequential seafloor cable breaks at the start of the last century provided the first direct evidence of subaqueous avalanches of sediment called 'turbidity currents' (Heezen and Ewing 1952, 1955; Shepard 1954; Heezen et al. 1964; Ryan and Heezen 1965; Piper et al. 1988; Pope et al. 2017). These seafloor-hugging flows were shown to be powerful (reaching up to $20 \mathrm{~m} \mathrm{~s}^{-1}$, sustaining speeds of $3-10 \mathrm{~m} \mathrm{~s}^{-1}$ on slopes of less than $1^{\circ}$; Hsu et al. 2008; Carter et al. 2014) and capable of transporting large volumes of sand, mud, organic carbon and nutrients across vast distances (tens to hundreds of kilometres) (Krause et al. 1970; ElRobrini et al. 1985; Piper et al. 1988; Mulder et al. 1997). More than one million kilometres of seafloor cables now connect the world; transmitting more

From: Georgiopoulou, A., Amy, L. A., Benetti, S., Chaytor, J. D., Clare, M. A., Gamboa, D., Haughton, P. D. W., Moernaut, J. and Mountjoy, J. J. (eds) 2020. Subaqueous Mass Movements and their Consequences: Advances in Process Understanding, Monitoring and Hazard Assessments. Geological Society, London, Special Publications, 500, $605-634$. First published online May 22, 2020, https://doi.org/10.1144/SP500-2019-173

(C) 2020 The Author(s). This is an Open Access article distributed under the terms of the Creative Commons Attribution License (http://creativecommons.org/licenses/by/4.0/). Published by The Geological Society of London.

Publishing disclaimer: www.geolsoc.org.uk/pub_ethics 
than $98 \%$ of all digital data communications, including the internet and financial trading (Burnett and Carter 2017). We are increasingly reliant on this global network and on networks of subsea pipelines that support a growing demand for energy (Yergin 2006; Carter 2010). It is therefore important to understand the hazards posed to this critical seafloor infrastructure by seafloor mass movements, such as turbidity currents, to inform safe routing, geohazardtolerant design or mitigation measures where necessary (Bruschi et al. 2006; Randolph and White 2012; Syahnur and Jaya 2016; Sequeiros et al. 2019). In addition to being potential geohazards, turbidity currents are also globally important agents of particulate and pollutant transport (Piper et al. 1988; Pohl et al. 2020). We want to know information such as: (i) how they are triggered and linked to onshore sedimentary systems; (ii) the frequency at which they recur; (iii) how they interact with the seafloor; (iv) the physical controls on their run-out; and (v) their internal velocity and sediment concentration structure. Inferences can be gleaned from the study of ancient deposits, through analogue modelling of scaled-down flows in the laboratory and from numerical modelling; however, direct field-scale measurements are needed to calibrate and/or validate all of these approaches (Xu 2011; Fildani 2017).

\section{A very brief history of monitoring turbidity currents}

Monitoring turbidity currents poses several challenges because deploying instruments on the deep seafloor is logistically challenging, flows may occur infrequently and the powerful nature of flows can damage the instruments intended to measure them (e.g. Inman et al. 1976; Talling et al. 2013; Puig et al. 2014; Clare et al. 2017; Lintern et al. 2019). Despite these challenges, several studies have prevailed to provide direct measurements of turbidity currents, including seminal field campaigns using point current meters (that measure velocity at one elevation in the water column), in settings ranging from active river-fed fjords (Hay 1987a, $b$; Hay et al. 1982; Prior et al. 1987; Syvitski and Hein 1991; Bornhold et al. 1994), lakes (Lambert and Giovanoli 1988) to deep-sea submarine canyons (Gennesseaux et al. 1971; Inman et al. 1976; Shepard et al. 1977; Khripounoff et al. 2003, 2009; Vangriesheim et al. 2009). These initial pioneering studies demonstrated that some systems can feature tens of turbidity currents in a year and that it is feasible to measure flows of up to $3.5 \mathrm{~m} \mathrm{~s}^{-1}$ (Prior et al. 1987). These studies were not without incident, however. Many involved damaged or lost instruments (Table 1). Those early studies were also limited with respect to the temporal resolution of measurements, data storage capabilities, duration of deployments and did not permit depth-resolved flow measurements (Talling et al. 2013).

Recent developments in technology, most notably the development of instruments such as Acoustic Doppler Current Profilers (ADCPs) and longendurance lithium batteries, have enabled depthresolved measurements of velocity and acoustic backscatter (a proxy measurement for sediment concentration; Thorne and Hanes 2002) (Cacchione et al. 2006; Shih 2012). Downward-looking ADCPs avoid the need for numerous individual point measurements made from within flows (Xu 2011; Khripounoff et al. 2012). In recent years, a growing number of ADCP-based measurements of turbidity currents have been made in locations including submarine canyons and channels offshore California (Puig et al. 2004; Xu et al. 2004, 2010; Paull et al. 2018), Mississippi (Ross et al. 2009), NE Atlantic (de Stigter et al. 2007; Martín et al. 2011; Mulder et al. 2012), Mediterranean (Khripounoff et al. 2012; Puig et al. 2012; Martín et al. 2014; Ribó et al. 2015) British Columbia (Hughes Clarke 2016; Lintern et al. 2016; Hage et al. 2018, 2019), West Africa (Cooper et al. 2013, 2016; AzpirozZabala et al. 2017a, b) and Taiwan (Liu et al. 2012; Zhang et al. 2018).

Modern turbidity current monitoring campaigns typically integrate multiple sensors and tools, such as multibeam sonar (imaging the water column), optical backscatter sensors (to detect suspended particles), acoustic monitoring transponders (to determine seafloor movement) and sediment traps (to collect suspended sediment) (Lintern and Hill 2010; Xu 2011; Khripounoff et al. 2012; Hughes Clarke 2016; Lintern et al. 2016, 2019; Clare et al. 2017; Paull et al. 2018; Hage et al. 2019; Maier et al. $2019 a, b)$. The tools that can be used to measure turbidity currents are partly covered by a number of reviews (Xu 2011; Talling et al. 2013; Puig et al. 2014; Clare et al. 2017). Here, we focus on the platforms on which these instruments or sensors are mounted, that may include devices such as moorings or frames installed on the seafloor and may be autonomous or connected via a cabled power and communications link. Examples of different types of platforms are illustrated in Figure 1.

\section{Aims}

Recent findings enable us to test, refute and refine established hypotheses in turbidity current science; however, direct measurements only exist from a relatively small number of sites worldwide. Many types of system and regions remain completely unrepresented. To date, no detailed measurements of velocity or sediment concentration have been published in water depths of $>2 \mathrm{~km}$ and none from 
Table 1. Examples of adverse effects to monitoring platforms and instruments caused by turbidity currents from previous studies and sites referenced in this paper

\begin{tabular}{|c|c|c|c|c|}
\hline Location and literature source & Instrument type & $\begin{array}{l}\text { Water } \\
\text { depth }(m)\end{array}$ & $\begin{array}{l}\text { Maximum } \\
\text { measured velocity } \\
\left(\mathrm{m} \mathrm{s}^{-1}\right)\end{array}$ & Documented adverse effects, damage, etc. \\
\hline $\begin{array}{l}\text { Scripps Canyon (Inman 1970; Inman } \\
\text { et al. 1976) }\end{array}$ & $\begin{array}{l}\text { Point current meter } 4 \mathrm{~m} \text { above } \\
\text { seafloor connected to shore by a } \\
\text { cable }\end{array}$ & 46 & 1.9 & $\begin{array}{l}\text { Current meter failed during flow and was subsequently lost. } \\
\text { Flows bent a } 2.5 \mathrm{~cm} \text {-thick solid steep rod bolted into } \\
\text { canyon bedrock }\end{array}$ \\
\hline $\begin{array}{l}\text { Lake Geneva, Switzerland (Lambert } \\
\text { and Giovanoli 1988) }\end{array}$ & $\begin{array}{l}\text { Point current meters on single-point } \\
\text { moorings }\end{array}$ & Up to 170 & Up to 3 & Anchor cables broke and moorings floated to surface \\
\hline $\begin{array}{l}\text { La Jolla Canyon, California (Shepard } \\
\text { and Marshall 1973) }\end{array}$ & $\begin{array}{l}\text { Point current meters on single-point } \\
\text { mooring }\end{array}$ & 200 & $\begin{array}{l}\text { Up to } 0.5 \text { before } \\
\text { data recording } \\
\text { stopped }\end{array}$ & Moorings displaced $500 \mathrm{~m}$ down-canyon \\
\hline $\begin{array}{l}\text { Open slope, Hawaii (Dengler et al. } \\
\text { 1984) }\end{array}$ & $\begin{array}{l}\text { Point current meters on single-point } \\
\text { mooring }\end{array}$ & Up to 600 & Up to 2 & Episodic downslope movement of moorings by $2.4 \mathrm{~km}$ \\
\hline $\begin{array}{l}\text { Squamish Delta, British Columbia } \\
\text { (Hughes Clarke } \text { et al. 2012; } \\
\text { Hughes Clarke 2016) }\end{array}$ & $\begin{array}{l}\text { Upward-facing ADCP mounted in } \\
\text { seabed frame }\end{array}$ & Up to 150 & Up to 1.5 & ADCP frame buried by $2 \mathrm{~m}$ of sediment. \\
\hline $\begin{array}{l}\text { Fraser Delta, British Columbia } \\
\quad \text { (Lintern et al. 2016) }\end{array}$ & $\begin{array}{l}\text { Cabled seafloor frame }(1 \mathrm{t}) \text { fitted } \\
\text { with numerous instruments } \\
\text { including upward-facing ADCP }\end{array}$ & $40-107$ & Up to 10 & $\begin{array}{l}\text { Platform tumbled down delta and severed connection with } \\
\text { onshore cable }\end{array}$ \\
\hline $\begin{array}{l}\text { Bute Inlet, British Columbia (Prior } \\
\text { et al. 1987) }\end{array}$ & $\begin{array}{l}\text { Point current meters, Anderson-style } \\
\text { sediment traps on single point } \\
\text { moorings. Seafloor frame vane } \\
\text { deflectors }\end{array}$ & Up to 520 & Up to 3.4 & $\begin{array}{l}\text { Rotors and vanes on current meters broken off or fouled } \\
\text { (causing poor data quality), shackles and stainless steel } \\
\text { frames bent and sheared, some entire instruments lost. } \\
\text { Mooring wires parted, releasing instruments to surface. } \\
\text { Moorings displaced along- and down-channel (up to } \\
1 \mathrm{~km} \text { ). Acoustic releases failed to detach due to assumed } \\
\text { burial by sand. }\end{array}$ \\
\hline $\begin{array}{l}\text { Monterey Canyon, California (Paull } \\
\text { et al. 2002) }\end{array}$ & $\begin{array}{l}\text { Seafloor trapezoidal frame }(97 \times 83 \\
\mathrm{cm} \text { base and } 48 \mathrm{~cm} \text { tall })\end{array}$ & 525 & $\mathrm{~N} / \mathrm{A}$ & $\begin{array}{l}\text { Frame transported } 550 \mathrm{~m} \text { down-canyon and buried in up to } \\
0.7 \mathrm{~m} \text { of sediment. }\end{array}$ \\
\hline $\begin{array}{l}\text { Monterey Canyon California (Paull } \\
\text { et al. 2010) }\end{array}$ & $\begin{array}{l}\text { Trawl-resistant seafloor frames (up to } \\
1360 \mathrm{~kg} \text { ) }\end{array}$ & $\begin{array}{l}289 \text { and } \\
520\end{array}$ & $\mathrm{~N} / \mathrm{A}$ & $\begin{array}{l}\text { Moved up to } 170 \mathrm{~m} \text { down-canyon and buried in up to } 1.5 \mathrm{~m} \\
\text { sediment. }\end{array}$ \\
\hline $\begin{array}{l}\text { Monterey Canyon, California (Paull } \\
\text { et al. 2018) }\end{array}$ & $\begin{array}{l}\text { Array of single-point moorings, a } \\
\text { seafloor frame, and an } 800 \mathrm{~kg} \\
\text { frame carrying a transponder }\end{array}$ & $\begin{array}{l}\text { Up to } \\
1850\end{array}$ & Up to 7.2 & $\begin{array}{l}\text { MS1 transported } 7.1 \mathrm{~km} \text { down-canyon before breaking } \\
\text { loose and floating to surface, sediment traps torn apart, } \\
800 \mathrm{~kg} \text { frame transport } 4.5 \mathrm{~km} \text { down canyon and buried } \\
\text { in }>1 \mathrm{~m} \text { sand. }\end{array}$ \\
\hline $\begin{array}{l}\text { Congo Canyon, West Africa } \\
\text { (Khripounoff et al. 2003; } \\
\text { Vangriesheim et al. 2009) }\end{array}$ & $\begin{array}{l}\text { Point current meters on single-point } \\
\text { mooring }\end{array}$ & $\begin{array}{l}\text { Up to } \\
4790\end{array}$ & Up to 3.5 & $\begin{array}{l}\text { Tilting of mooring prior to parting of mooring anchor line, } \\
\text { releasing instruments to surface. Damaged current meter } \\
\text { ( } 30 \mathrm{~m} \text { above seafloor) and sediment trap ( } 40 \mathrm{~m} \text { above } \\
\text { seafloor) }\end{array}$ \\
\hline $\begin{array}{l}\text { Congo Canyon, West Africa (Cooper } \\
\text { et al. 2013; Azpiroz-Zabala et al. } \\
\text { 2017a) }\end{array}$ & $\begin{array}{l}\text { Downward-facing ADCP on } \\
\text { single-point mooring }\end{array}$ & 2000 & Up to 2.5 & $\begin{array}{l}\text { Rotating ADCP } \\
\text { Interference with canyon sidewall }\end{array}$ \\
\hline
\end{tabular}


source to deep-water sink (e.g. submarine fan) as the logistics of placing platforms in deep water remains challenging.

Our overarching aim is to share lessons learned from recent campaigns measuring powerful turbidity currents to enable more measurements to be made in a wider variety of locations and settings worldwide. We do this through the following specific objectives. First, we provide an overview of the challenges encountered during the measurement of powerful turbidity currents (up to $10 \mathrm{~m} \mathrm{~s}^{-1}$ ), including the tilting, displacement and damage of monitoring platforms. We illustrate these challenges with examples from systems including fjord-head deltas, a major river-fed canyon and an oceanographically fed canyon. Second, we introduce single-point moorings and how a successful design for monitoring turbidity currents may be used for more routine oceanographic purposes. These differences include requirements for extra anchor weighting, positive buoyancy and we discuss the implications of deploying large surface area instruments, such as sediment traps, that can induce excess drag on the mooring string. We outline several methods to reduce drag and enhance mooring stability. Third, we present a method to deploy two- and four-point moorings, anchored either side of a channel; ensuring that neither the instrument, nor the mooring line, interacts with flows. This is important where pronounced erosion or deposition may occur in the channel axis and to reduce mooring drag and tilt. Fourth, we assess the deployment of benthic landers and frame-based platforms, describing methods to enhance stability. Finally, we conclude with a discussion on future advances, in both sensor deployment and platform design, which will enable longer endurance turbidity current monitoring.

\section{Study areas and monitoring data}

We now introduce the case study sites discussed in this paper where frequent (sub-annual) turbidity currents have been measured (Fig. 2).

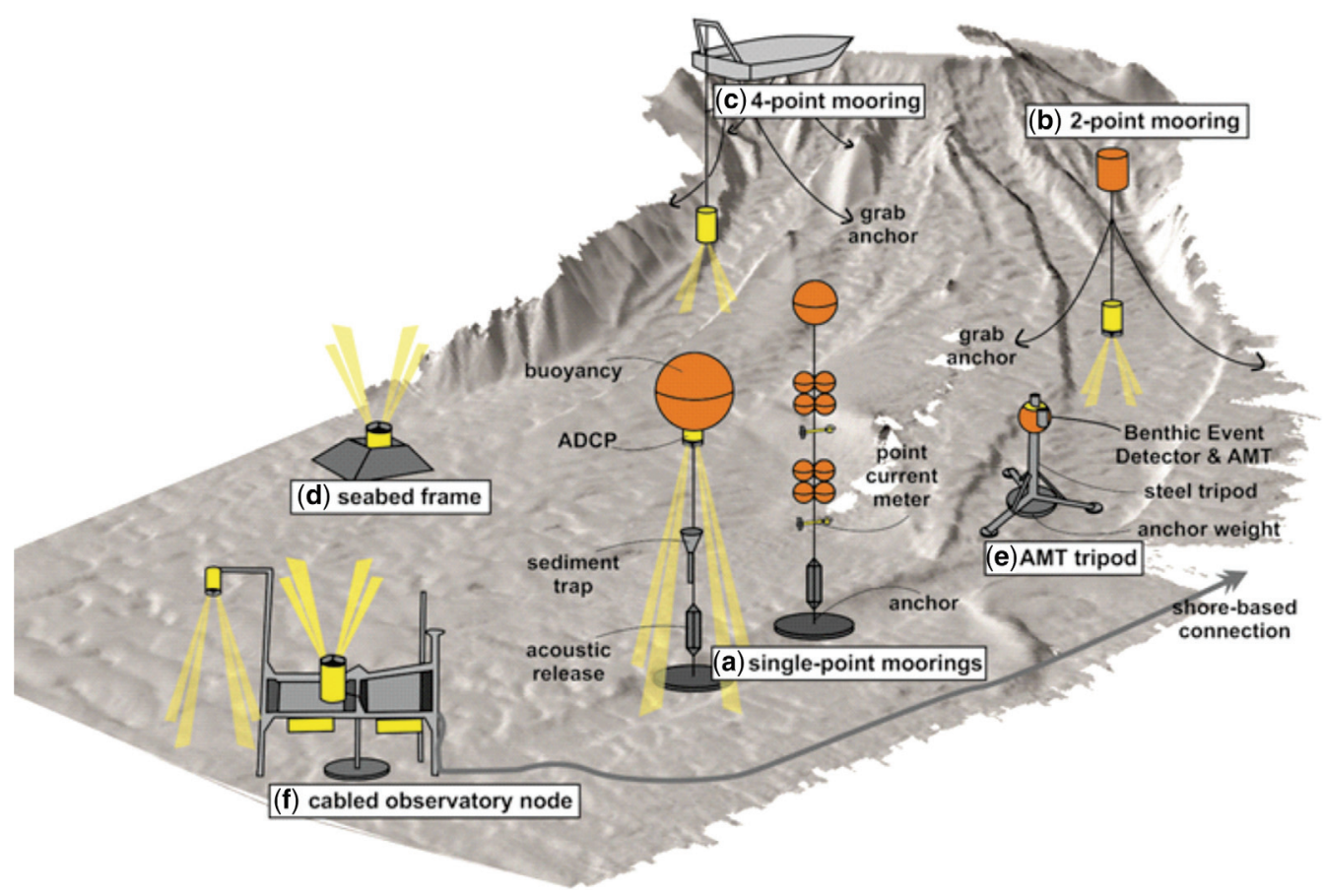

Fig. 1. Illustration depicting examples of some turbidity current monitoring platforms discussed in this paper, including: (a) single-point moorings (examples showing older point current meters (right) and more recent ADCP designs (left)) with anchors in the submarine channel axis; (b) two-point mooring to suspend a down-looking instrument above an active submarine channel, which avoids placement of the anchor in a channel axis; (c) four-point mooring to stabilize the orientation of a vessel and to enable deployment of suspended instruments (Hughes Clarke 2016); (d) seabed frame to deploy an upward-facing instrument; (e) Acoustic Monitoring Transponder (AMT) tripod with Benthic Event Detector (BED) to track movement (Paull et al. 2018); (f) platform connected to a seafloor cable network that may host many instruments with real-time communications and power (Lintern et al. 2016). 

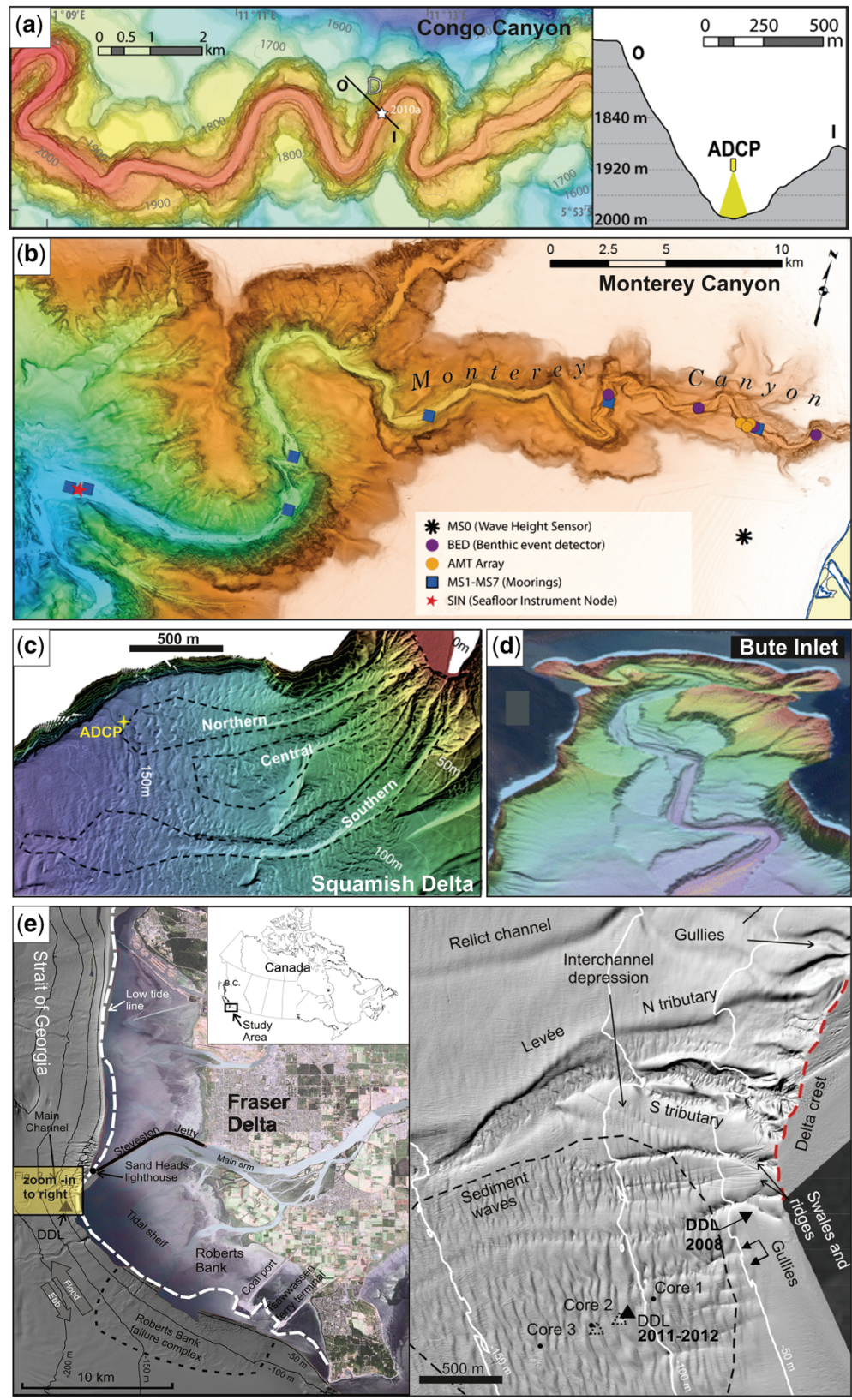

Fig. 2. Location maps and bathymetry for each of the sites discussed in this paper. (a) Location of ADCP mooring in Congo Canyon, West Africa at $2000 \mathrm{~m}$ water depth (modified from Azpiroz-Zabala et al. 2017a). (b) Configuration of Monterey Canyon CCE instrument deployment, offshore Moss Landing, California, USA. Water depth range of instrument deployment was $30 \mathrm{~m}$ to $1840 \mathrm{~m}$ (from https://www.mbari.org/cce-instruments-2019/). (c) Squamish submarine delta in Howe Sound, British Columbia. Water depth is up to $200 \mathrm{~m}$ (modified from Clare et al. 2016). (d) Bute Inlet, British Columbia, with water depths of up to $700 \mathrm{~m}$. (e) Fraser Delta, British Columbia, showing relationship with the Fraser River (left) and detail on offshore delta channel and bedform field (right) where the Delta Dynamics Laboratory (DDL) was deployed in different locations (modified from Lintern et al. 2016). 


\section{Congo Canyon, West Africa}

The Congo Canyon is the proximal part of one of the largest submarine channel systems on the planet and is fed directly by the Congo River (Heezen et al. 1964; Babonneau et al. 2010; Azpiroz-Zabala et al. 2017b). Here we focus on previously published ADCP measurements in the upper part of the Congo Canyon ( $2 \mathrm{~km}$ water depth) that revealed a high frequency of turbidity current activity (Fig. 2a; Cooper et al. 2013). Eleven turbidity currents were measured using a downward-looking ADCP (measuring every $5 \mathrm{~s}$ ) deployed from singlepoint moorings. Flows reached velocities of up to $2.5 \mathrm{~m} \mathrm{~s}^{-1}$ and lasted up to 10 days in duration, accounting for $30 \%$ of the four-month monitoring period (Azpiroz-Zabala et al. 2017a).

\section{Monterey Canyon, Pacific coast, USA}

Monterey Canyon extends from its shelf-incising head in Monterey Bay to the deep-sea Monterey Fan, and is one of the largest submarine canyons on the Pacific Coast of North America (Normark et al. 2003; Paull et al. 2005). Sediment is supplied to the canyon head by long-shore sediment transport cells, rather than directly from a river source (Best and Griggs 1991). Frequent turbidity currents have been recorded by numerous studies in the canyon using downward-looking ADCPs on single-point moorings (e.g. Xu and Noble 2009; Xu et al. 2013, 2014). A recent (2015-17) 18-month co-ordinated international experiment installed more than 50 sensors within the canyon to record the passage of 15 turbidity currents; some of which ran out for $>50 \mathrm{~km}$ in water depths of up to $1840 \mathrm{~m}$ and reached velocities of $>7.2 \mathrm{~m} \mathrm{~s}^{-1}$ (Paull et al. 2018; Heerema et al. 2020; Fig. 2b). Here, we focus on four different types of platform: (i) a downward-looking ADCP and sediment trap (at $290 \mathrm{~m}$ water depth; Maier et al. 2019a); (ii) an $800 \mathrm{~kg}$ tripod frame (deployed at $300 \mathrm{~m}$ water depth) fitted with an Acoustic Monitoring Transponder (AMT) and Benthic Event Detector (BED) to track its movement (Paull et al. 2018; Urlaub et al. 2018); and (iii) a seafloor frame deployed at the distal end of the monitoring array (1840 m water depth) that hosted numerous instruments including upward-looking ADCPs (Paull et al. 2018).

\section{Squamish prodelta, Canadian Pacific Coast}

The Squamish prodelta lies offshore from the Squamish River that drains into the Howe Sound fjord, British Columbia. Three submarine channels connect the delta lip to channel lobes in water depths of up to $200 \mathrm{~m}$ (Fig. 2c: Hughes Clarke 2016). Repeat seafloor surveys and water column monitoring have revealed extremely frequent $(>100$ per year) turbidity currents during seasonal peaks in meltwater discharge (Hughes Clarke et al. 2012; Clare et al. 2016). Here we focus on a seafloor frame containing an upward-looking ADCP (installed on the terminal lobe of one of the channels in 2011; Fig. 2c), and multi-point moorings installed in 2013 and 2015 to measure flows that attained velocities of up to $3 \mathrm{~m} \mathrm{~s}^{-1}$ (Hughes Clarke 2016; Hage et al. 2018).

\section{Bute Inlet, Canadian Pacific Coast}

Bute Inlet fjord (also in British Columbia) is fed by the Homathko and Southgate rivers, which in turn feed the submarine deltas at the head of a sinuous $50 \mathrm{~km}$-long submarine channel that extends to a terminal lobe at c. $700 \mathrm{~m}$ water depth (Fig. 2d; Prior et al. 1987). Repeated seafloor surveys have shown $>$ metre-scale elevation changes in the channel axis due to erosion and deposition caused by turbidity currents (Gales et al. 2019). Some of the earliest direct measurements of turbidity currents were made in Bute Inlet using point current meters on moorings that recorded flows in excess of $3 \mathrm{~m} \mathrm{~s}^{-1}$ (Prior et al. 1987; Zeng et al. 1991). Here, we focus on more recent ADCP- and $500 \mathrm{kHz}$ multibeam echosounder-based measurements of flows using two- and four-point moorings, deployed in 2016 and 2018.

\section{Fraser Delta, Canadian Pacific Coast}

The Fraser submarine delta lies offshore from the Fraser River, British Columbia. The principal offshore distributary channel is located immediately seaward of the river outflow and is flanked to its south by a field of sediment waves on the delta slope (Fig. 2e; Lintern et al. 2016). Historical slope failures have been observed from repeat seafloor surveys on the submarine delta slope (e.g. Kostaschuk et al. 1992; Hill 2012). Unlike the previous examples, here we focus on an array of monitoring platforms installed outside of a submarine channel the Delta Dynamics Laboratory (DDL), sited on the open sediment wave field (Fig. 2e). The DDL is part of Ocean Network Canada's Victoria Experimental Network Under the Sea (VENUS) cabled network and has been in operation since 2008 (Lintern and Hill 2010; Lintern et al. 2016). The platform can host a wide range of instrumentation due to its cabled power and communications connection, some of which include upward- and downwardlooking ADCPs, velocity profilers, turbidity sensors and video cameras (Lintern et al. 2016). Other platforms at the site include a Seismic Liquefaction In situ Penetrometer (SLIP), which measures pressures and movement within the bed, and a 
hydrophone array, which listens for landslides and other environmental noises. As with the Bute and Squamish sites, turbidity currents are frequent during the spring and summer when river discharge is elevated (Ayranci et al. 2012).

\section{Results from recent direct monitoring of turbidity currents}

We now summarize the issues we encountered during recent turbidity current monitoring campaigns, ordered from the smallest to greatest impact.

\section{Temporary instability of single-point moorings: pull down, pitch, roll and rotation}

Single-point ADCP moorings in a submarine canyon or channel axis commonly record an abrupt increase in water pressure coincident with the arrival of a turbidity current. In the 2015-17 Monterey Canyon Coordinated Canyon Experiment (CCE), each of the 15 turbidity currents caused an initial increase in water pressure that generally declined over 4-120 minutes (Paull et al. 2018). This increase in water pressure is attributed to pulldown of the mooring cable, due to drag imparted by the flow front (which reached velocities of up to $7.2 \mathrm{~m} \mathrm{~s}^{-1}$ ) most likely exerted on instruments that were within the flow. A decrease in water pressure occurred when the flows decelerated and the mooring gradually returned to its original vertical position. A similar situation was observed in a previous experiment in Monterey Canyon, where a mooring was severely tilted during the first 15 minutes of a turbidity current, causing a sediment trap (located at $70 \mathrm{~m}$ above seafloor) to be pulled down by $37 \mathrm{~m}$ into the lower parts of the flow; thus explaining the anomalously coarse material collected by the sediment trap (Symons et al. 2017). Mooring tilt and down-canyon transport also occurred during strong internal tidal flows in Monterey Canyon (i.e. tidal frequency flows trapped within the canyon topography, unrelated to turbidity currents). On 30 November 2015, during a particularly strong up-canyon internal tide $\left(c .1 \mathrm{~m} \mathrm{~s}^{-1}\right)$, the lower current meter was pulled down $2 \mathrm{~m}$ and tilted more than $20^{\circ}$.

Such pull-down effects were not observed in the Congo Canyon, where the mooring construction was much simpler and acoustic release links were located much higher $(70 \mathrm{~m})$ above the seafloor than in the Monterey Canyon experiments ( $3 \mathrm{~m}$ above seafloor). This is not to say that the Congo Canyon mooring remained unaffected by flows, however. Intervals of increased pitch, roll and tilting $\left(<2^{\circ}\right)$ were recorded by the downward-looking ADCP during turbidity currents; dominantly during the initial passage $(<1 \mathrm{~h})$ of the fast frontal cell. These effects (in particular the rotation of the buoy housing the ADCP) resulted in transient interaction of the ADCP beams with the narrow canyon sidewalls, thus limiting the depth range and quality of velocity and backscatter measurements.

\section{Down-canyon transport of single-point moorings and damage to instruments}

As well as the reversible pressure changes noted at the start of turbidity currents, several turbidity currents in Monterey Canyon caused permanent pressure and temperature changes, as recorded by ADCPs on single-point moorings. These irreversible changes indicate that, in addition to the buoymounted ADCP being temporarily pulled towards the seafloor, single-point moorings were also transported down-canyon. Symons et al. (2017) documented the $580 \mathrm{~m}$ down-canyon transport of a single-point mooring attached to a $1000 \mathrm{~kg}$ anchor at a speed of $c .0 .5 \mathrm{~m} \mathrm{~s}^{-1}$ from a 2002-03 deployment (Xu et al. 2004, 2014). During the CCE (1 December 2015), a single-point mooring (using a $450 \mathrm{~kg}$ train wheel for an anchor) was moved down-canyon (as evidenced by an average drop in pressure of $3 \mathrm{~m}$ ) by a relatively small turbidity current $\left(c .3 \mathrm{~m} \mathrm{~s}^{-1}\right)$. The most powerful flow event (15 January 2016) caused down-canyon transport of the same mooring by $7.1 \mathrm{~km}$, at an average speed of $4.5 \mathrm{~m} \mathrm{~s}^{-1}$ (Paull et al. 2018). This mooring ultimately broke loose from its anchor and was retrieved at the sea surface.

On the final of three deployments in the Monterey Canyon CCE, two train wheels (c. $900 \mathrm{~kg}$ ) were used to anchor the single-point mooring and inline flotation was placed above each sediment trap (as well as additional flotation at the top of the mooring; Fig. 3). Mooring performance was much improved by this revised design. Even in very strong turbidity currents $\left(>5 \mathrm{~m} \mathrm{~s}^{-1}\right)$ the mooring did not move. Tilt and down-pull during strong internal tides were also considerably reduced $\left(<10^{\circ}\right.$ and $<1 \mathrm{~m}$, respectively). To make additional measurements within turbidity currents, several instruments were installed on the mooring line beneath the ADCP for the Monterey CCE, including Anderson-style sediment traps, altimeters and a point current meter (Fig. 3a-c). Significant damage was recorded upon retrieval of these instruments, however, including loss of the impellors for the current meter, fouling of instruments with sediment and organic debris, removal of the sediment trap inlet funnel, and sand-blasting, bending and buckling of steel instrument frames (Paull et al. 2018; Maier et al. 2019a; Fig. 3d, e). One particularly important issue also concerned damage to the acoustic release links that are required for remote 

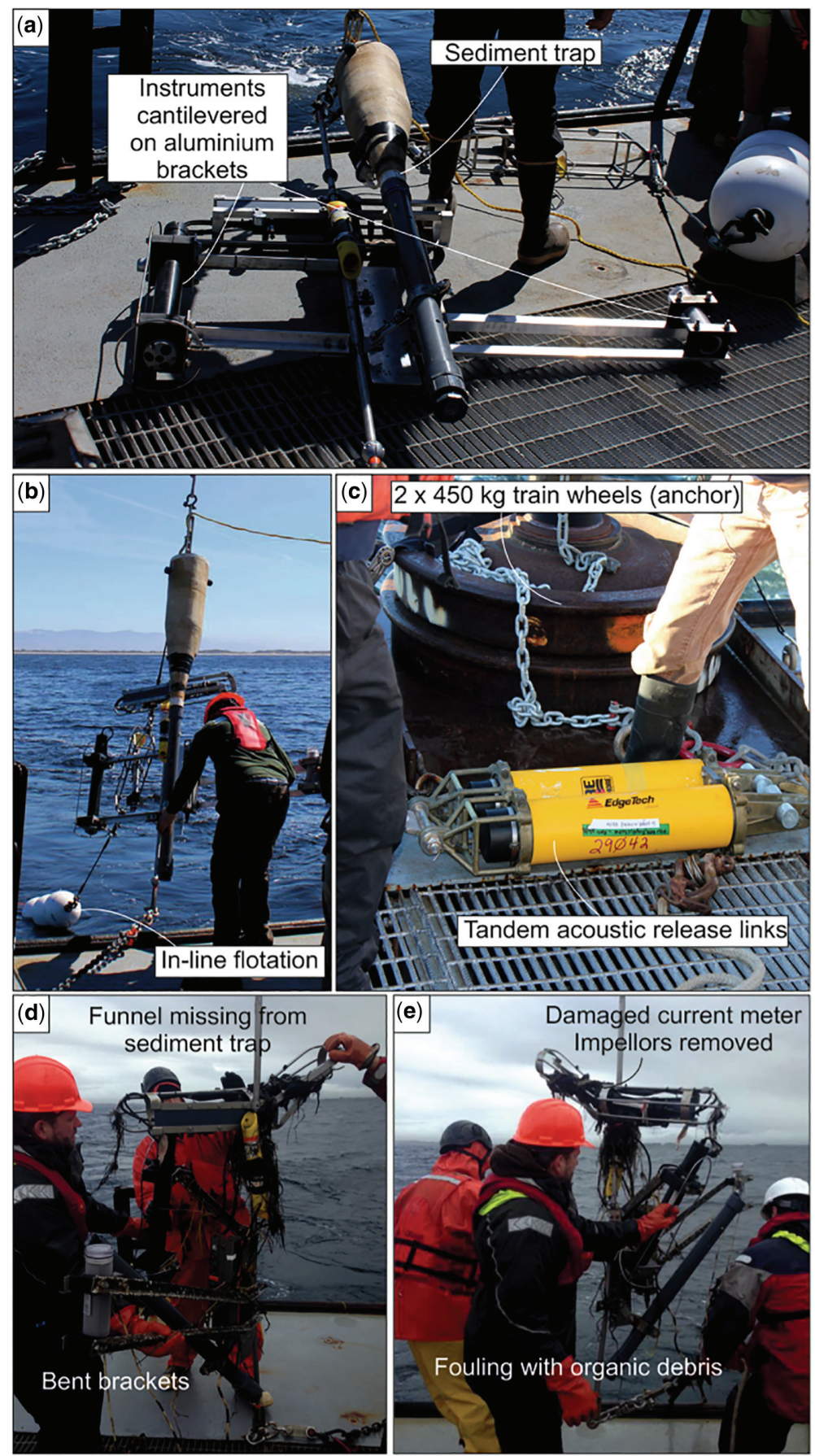

Fig. 3. Photographs of a sediment trap and inline instruments placed within turbidity currents from Monterey Canyon. (a) Pre-deployment photograph of a sediment trap and instruments fitted on cantilevered aluminium brackets. (b) Deployment of a sediment trap. (c) Detail on anchor weight (train wheels) and acoustic release links, which were placed $3 \mathrm{~m}$ above seafloor. (d, e) Sediment trap and instrument brackets following retrieval, showing damage and fouling during interaction with turbidity currents. 
release of the mooring and retrieval from the sea surface. Many of the releases (located at $10 \mathrm{~m}$ above seafloor) used in the Monterey CCE did not release properly when the command was issued from the support vessel. The extreme case was the final deployment where every mooring required a Remotely Operated Vehicle (ROV) dive to recover the mooring. Some of these required cutting of the mooring string below the release, while others only required tapping the release with the ROV's mechanical arms. These issues were attributed to the presence of sand within the releases and are similar to those encountered by single-point moorings in the submarine channel in Bute Inlet, where Prior et al. (1987) recorded: (i) damage, removal and fouling of rotors and vanes on current meters (causing poor data quality); (ii) bent and sheared shackles and stainless steel frames; (iii) up to $1 \mathrm{~km}$ down-channel transport of moorings; (iv) failure of acoustic releases to detach due to burial by sand; (v) parting of mooring lines; and (vi) the entire loss of some instruments (also detailed in Zeng et al. 1991).

Unlike these examples from Monterey Canyon and Bute Inlet, no irreversible pressure or temperature changes were observed for the single-point mooring in the Congo Canyon. Therefore the Congo Canyon mooring is unlikely to have been moved by any of the eleven turbidity currents that occurred during its deployment (Azpiroz-Zabala et al. 2017a, b). Furthermore, no damage was recorded in this case to either the acoustic release links or the ADCP. No other instruments were placed on the mooring line.

\section{Burial, downslope transport and damage of seabed frames}

We now discuss issues that have affected seabedbased platforms. An upward-looking ADCP was mounted on a bottom-mounted tripod in 2011 and deployed at the terminal end of a submarine channel offshore from the Squamish river delta (150 m water depth). This ADCP recorded 22 turbidity currents of up to $c .1 .5 \mathrm{~m} \mathrm{~s}^{-1}$ over a period of four months (Hughes Clarke et al. 2012), with the exception of a 20-day period when the run-out from a delta lip collapse led to the burial of the frame (Clare et al. 2016). With a single ensemble averaging interval of $20 \mathrm{~s}$, the ADCP went from recording flow to being completely buried. Thus, no monitoring was possible during this time. Interestingly the ADCP frame was not significantly tilted in this process. Fortunately, a vertically offset surface buoy was attached so that the instrument could be dragged out of the sediment.
In addition to the movement of single-point moorings deployed in the Monterey CCE, downcanyon movement of an $800 \mathrm{~kg}$ AMT-tripod-frame (Fig. 4a) was also recorded six times. These episodes of movement corresponded to the timing of turbidity currents. On 15 January 2016, the AMT frame moved $4.2 \mathrm{~km}$ down-canyon and was observed from ROV video to be on its side, half-embedded in the seafloor (Paull et al. 2018). The heavy-duty steel frame was transported within a dense sediment layer, its feet bent and sheared in places, while much of the pressure-resistant foam coating was abraded from the BED (Fig. 4d-f). Following its redeployment, the mooring was transported $0.9 \mathrm{~km}$ on 24 November 2016; also found on its side, but this time buried by at least $2 \mathrm{~m}$ of sediment with only one foot protruding at the seafloor (Fig. 4c). Pressure, temperature and accelerometer measurements indicate that once the AMT frame was tilted on to its side it became buried during the initial turbidity current and then remained in that position until it was moved by successive flows. A multi-instrument 'Seafloor Instrument Node' (SIN) was placed in a deeper water location (1840 m), where the Monterey Canyon widens. Flows decelerate from $c .4-8 \mathrm{~m} \mathrm{~s}^{-1}$ in the upper part of the canyon where the AMT frame was deployed to $c$. $1-2 \mathrm{~m} \mathrm{~s}^{-1}$ at the SIN location (Fig. 5; Paull et al. 2018; Heerema et al. 2020). Impacts of turbidity currents were less severe at this more distal location; however, the SIN frame was also transported down-canyon, by $26 \mathrm{~m}$, and was locally buried by up to $34 \mathrm{~cm}$ of sediment (Fig. 5c). A high frequency acoustic instrument (Aquadopp) was ripped from the arm that suspended it above seafloor and up to $10 \mathrm{~cm}$ of scour was noted from repeated ROV-based bathymetric surveys (Fig. 5b, c).

Even benthic landers sited outside of submarine channels can suffer from adverse impacts that include burial and movement of the platform. The original Delta Dynamics Laboratory platform (DDL), deployed in 2008 on the Fraser Delta (located in a bedform field outside of the main submarine channel; Fig. 2e), was buried by as much as $1 \mathrm{~m}$ of sediment. Initially it was thought that this was simply natural sediment deposition from the Fraser River; however, it is now attributed to active turbidity currents (Lintern et al. 2016). Recovery using a vessel-deployed crane caused a large ship (the 1800 t CGS John P. Tully) to lean uncomfortably and snapped $9000 \mathrm{~kg}$ lines. The original platform design at the Fraser Delta had a large surface area, which also made it prone to tumbling during turbidity currents, as recorded by frame-mounted orientation sensors, and was therefore replaced by a lower-profile platform with weighted legs (Fig. 6; Lintern et al. 2016). This revised deployment included arms and poles that held instruments 

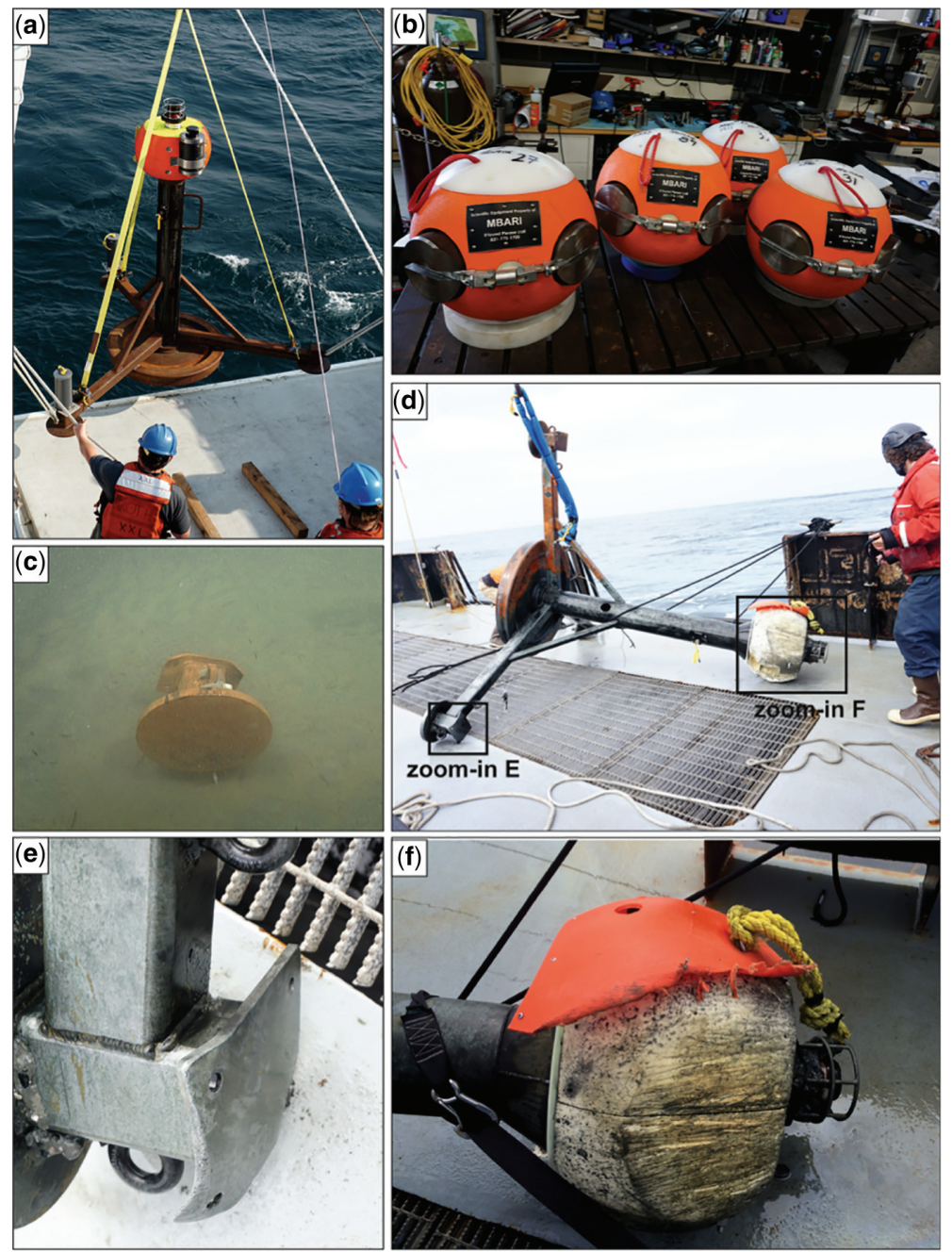

Fig. 4. Photographs of the $800 \mathrm{~kg}$ AMT frame deployed at $300 \mathrm{~m}$ in Monterey Canyon. (a) Prior to deployment of instrument. (b) Example of Benthic Event Detectors, one of which was attached to the top of the AMT frame to track the sense of motion of the frame. (c) Only the foot of the AMT frame was found protruding from seafloor by an ROV dive video following its burial by a turbidity current. (d) AMT frame following retrieval to deck, revealing damage to the frame (e) and flotation on the AMT frame (f) caused during its down-canyon transport.

away from the platform and above the $2 \mathrm{~m}$ powerful flows that were detected (Lintern et al. 2019). It also featured feet that snap free on retrieval, as embedment of the original large feet created problems during recovery (Fig. 6b). The second platform design mostly remained upright, but sometimes slid downslope during strong turbidity currents. To make it more resistant to flows, over $900 \mathrm{~kg}$ of ballast was suspended below the platform, while the legs penetrate the seafloor by up to $1 \mathrm{~m}$, acting as small piled foundations (Fig. 6c). This enhanced design has so far remained upright for two years, experiencing flows of up to $9 \mathrm{~m} \mathrm{~s}^{-1}$ (Lintern et al. 2016, 2019).

Other platforms on the Fraser Delta include a Benthic Boundary Laboratory (BBL) and a SLIP (Fig. 7). The BBL's main design feature was a cantilever to hold instruments away from the main platform to minimize frame turbulence. Despite the increased tipping moment this would appear to cause, it is worth noting that further down the delta slope $(140 \mathrm{~m} \mathrm{v}$. the DDL $107 \mathrm{~m})$ there has not been a strong enough turbidity current in five years of deployment to topple the deeper BBL. 

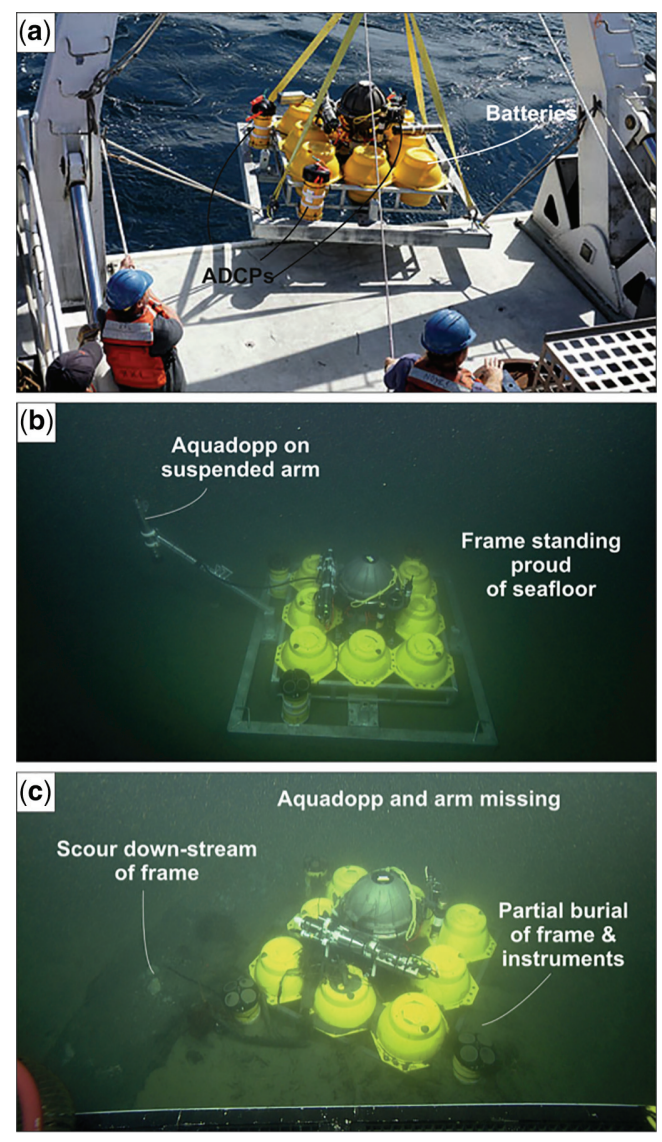

Fig. 5. Photographs of the Seafloor Instrument Node (SIN), deployed at $1840 \mathrm{~m}$ water depth in Monterey Canyon. (a) SIN prior to deployment. (b) ROV video still showing deployed location where the frame sits proud of the seafloor. (c) ROV video still at retrieval, following $26 \mathrm{~m}$ down-canyon transport, with evidence of local scour and deposition around the frame and removal of the Aquadopp and its mounting arm.

The SLIP is an instrument designed to measure pore pressures that could be associated with subaqueous mass movements (Fig. 7). It is constructed of a fibreglass frame above the seafloor holding a system of valves, data-loggers, instruments and a network plug. The data logging is done on cyclical buffers and has backup battery power in case it is severed from the network. The lower part of the SLIP is a $5 \mathrm{~m}$-long cone tip with multiple pressure and temperature ports. An $800 \mathrm{~kg}$ piston core head weight is used to push the SLIP tip into the sediment. The SLIP has been deployed for several years at the site of the DDL and due to its $5 \mathrm{~m}$ embedded tip, it has not suffered any translation from the same turbidity currents that have been tumbling the DDL platforms.

\section{Overview of adverse impacts related to turbidity currents}

Based on past experiences from recent monitoring campaigns, the following observations can be summarized about the hazards posed by turbidity currents to moorings and seafloor platforms (Fig. 8):

(1) The powerful dense near-bed part of a turbidity current (particularly prone in proximal confined submarine canyons or channels) may be capable of toppling and/or transporting heavy objects (in excess of hundreds of kilograms), including anchors and seabed frames (Fig. 8a). This dense part of the flow can damage platforms, sensors and ancillary mounting equipment through collisional impact or drag, and may even result in short-lived liquefaction of seafloor sediments, causing anchors for single-point moorings or seafloor frames to sink.

(2) Fast flows may pull instruments down towards the seafloor and, in some cases, overcome the tractional forces required to keep the anchor in place, and transport single-point moorings down-channel (Fig. 8a).

(3) Where instruments interact with a turbidity current, this may lead to platform instability and poor-quality data, damage to acoustic releases (jeopardizing successful retrieval of moorings) or, in severe cases, loss of instruments and mooring components (Fig. 8c).

(4) Erosion of the seafloor may change local seafloor elevation and undermine platforms where it occurs as scour around a seafloor structure (Fig. 8d).

(5) Sudden deposition, sometimes involving several metres thickness of sediment, can bury seafloor instruments or low-elevation acoustic releases, limiting instrument performance and causing issues for retrieval (Fig. 8d).

\section{Designing monitoring platforms to successfully measure turbidity currents}

In this section we highlight some of the lessons we have learned from previous turbidity current monitoring campaigns, in order to inform future ones.

\section{Finding a 'sweet spot' for the design of single-point moorings}

When optimizing mooring design to address one issue, other complications may arise concerning another. We now discuss how mooring designs have been iteratively refined to try and find the ideal configuration for different settings and objectives. 

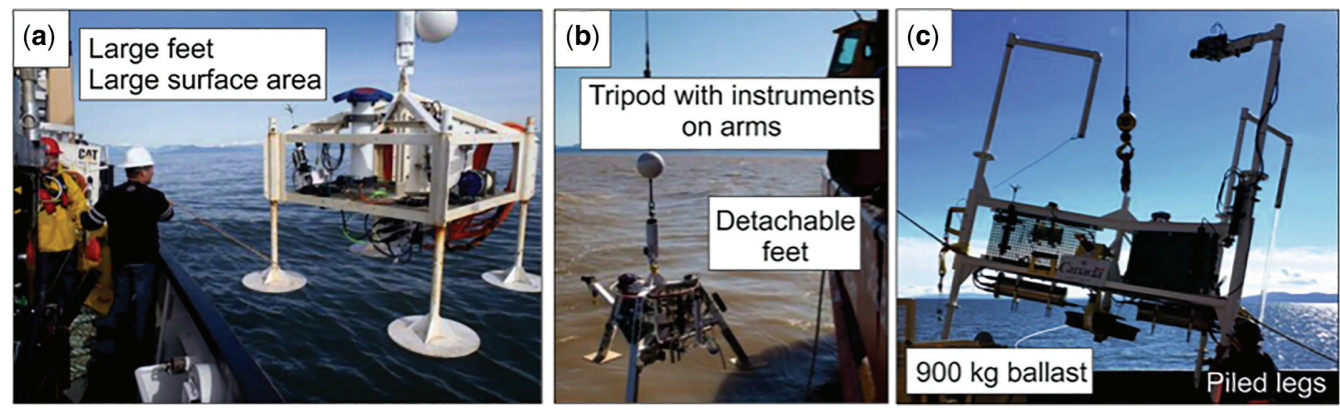

Fig. 6. Development of the Fraser Delta Dynamics Laboratory including (a) conventional design with large feet to stop embedment, (b) revised tripod design with detachable feet. Both (a) and (b) tumbled downslope during powerful flows. (c) Revised design that has withstood numerous powerful flows to date due to its piled legs and ballast weight that can be ejected. Image modified from Lintern et al. (2019).

Reduce the surface area to minimize drag. Singlepoint moorings are typically the preferred way to monitor turbidity currents as they can be deployed from the back deck of an ocean-going vessel equipped with a suitable winch and A-frame. Successful monitoring of turbidity currents is strongly dependent on the mooring design. Single-point moorings in the Congo Canyon did not show any movement down-canyon during turbidity currents, nor were any of the instruments damaged. We identify three reasons for the stability of this Congo Canyon mooring. First, while the flows in Congo Canyon lasted many hours to days in duration, they were generally muddy and dilute flows (with the exception of a frontal cell of sand-rich, sediment-laden fluid), and relatively slow, reaching maximum velocities of $<3 \mathrm{~m} \mathrm{~s}^{-1}$ with an average of $<1 \mathrm{~m} \mathrm{~s}^{-1}$ (Azpiroz-Zabala et al. 2017a). Conversely, flows in the Monterey Canyon often reached velocities far in excess of this value, up to $7.2 \mathrm{~m} \mathrm{~s}^{-1}$,
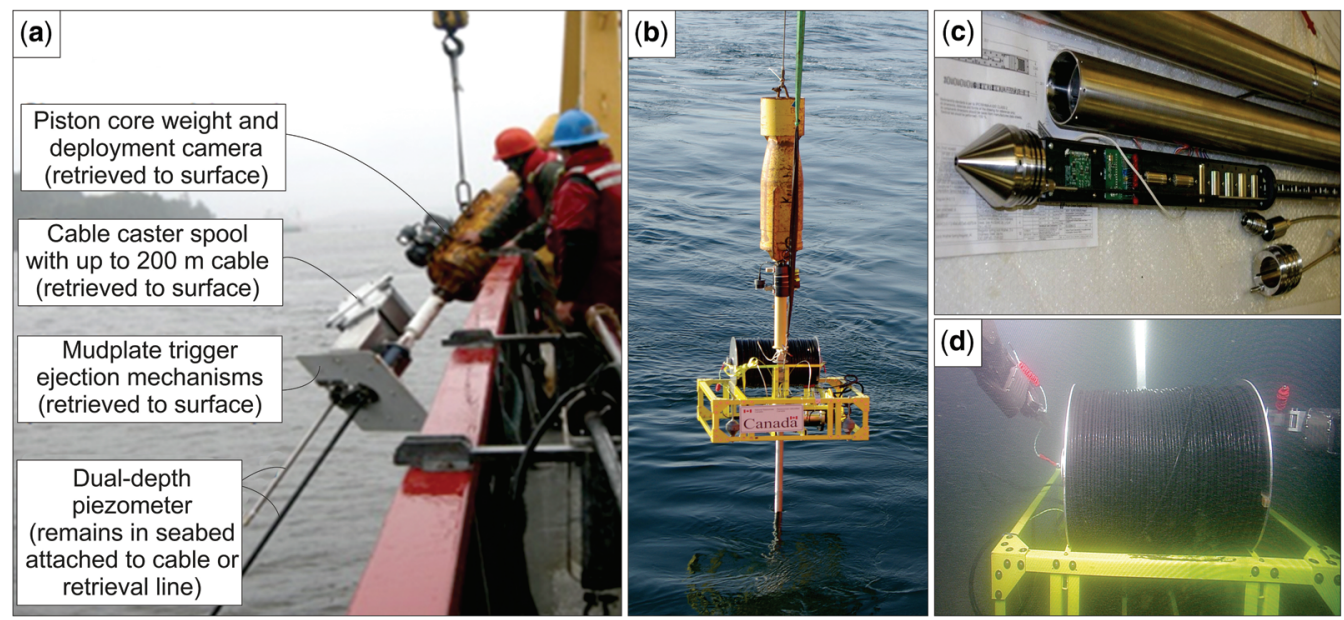

Fig. 7. Prototype benthic monitoring platforms at the Fraser Delta. A large stainless steel container houses data processing and logging instruments and an underwater modem. All components are made from fibreglass or stainless steel in an attempt to minimize corrosion in salt water. Power is provided by the network, and data are transmitted directly to the scientists' offices over the internet in near real time. A battery backup and circular buffer continue to measure data in case of a severed cable, due to a slope failure. (a) Overview of the NRCan Cable Caster (note this is a different design to the SLIP in (b)-(d)). The housing above the mud plate contains up to $200 \mathrm{~m}$ of cable. When the mud plate impacts the seafloor, the housing, deployment weight and camera are released and retrieved to the surface, unspooling the cable from the bottom for hookup to shore or to a data buoy. (b) Deployment of the prototype SLIP using $816 \mathrm{~kg}$ weight. (c) Detail on the instrumented tip of the SLIP that contains triaxial geophones to measure earthquakes and ground movements, measuring up to 100 times per second. (d) The SLIP cable being unspooled $1.5 \mathrm{~km}$ to the Victoria Experimental Network Under the Sea (VENUS) node by the manipulator arms of an ROV. 

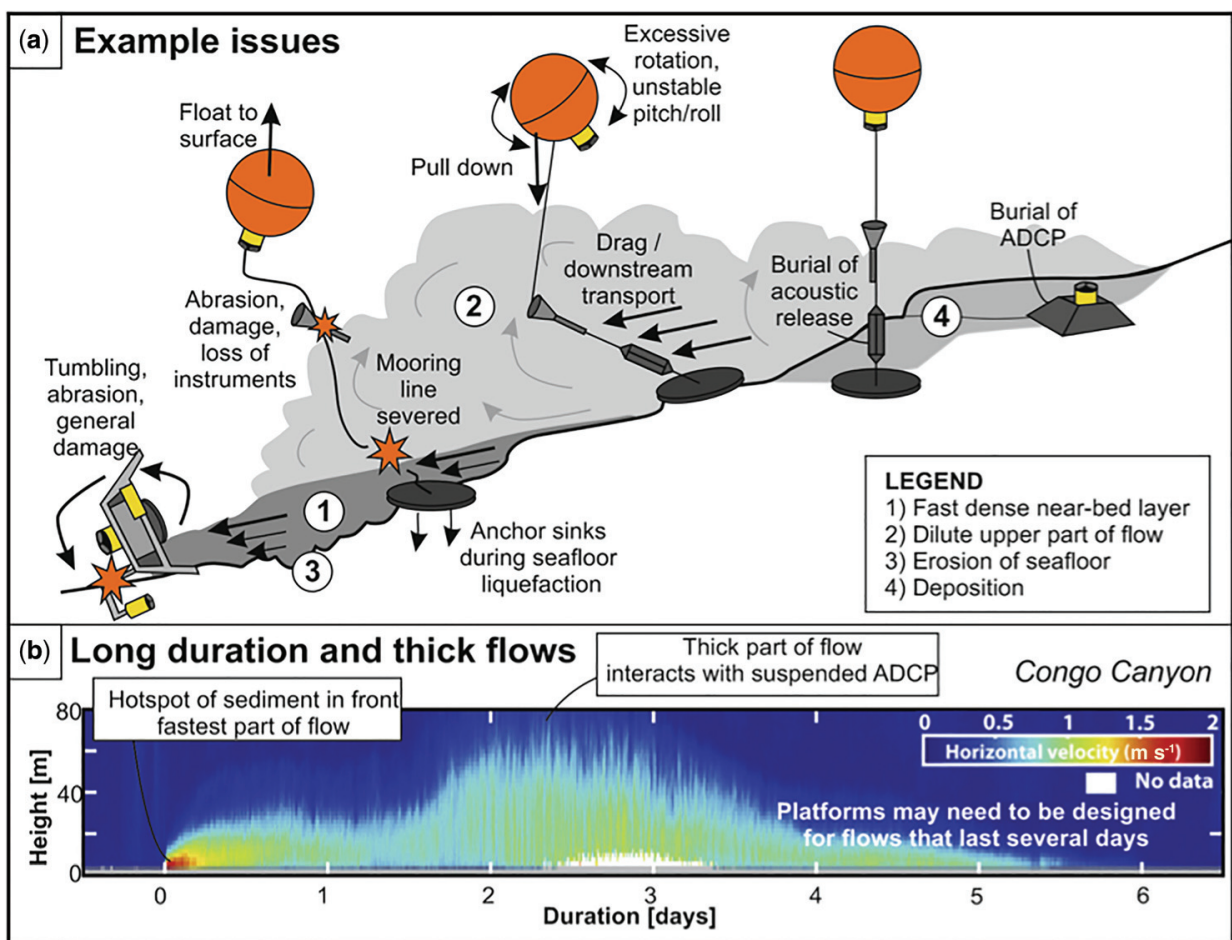

(c) Powerful flows capable of carrying heavy objects Monterey Canyon
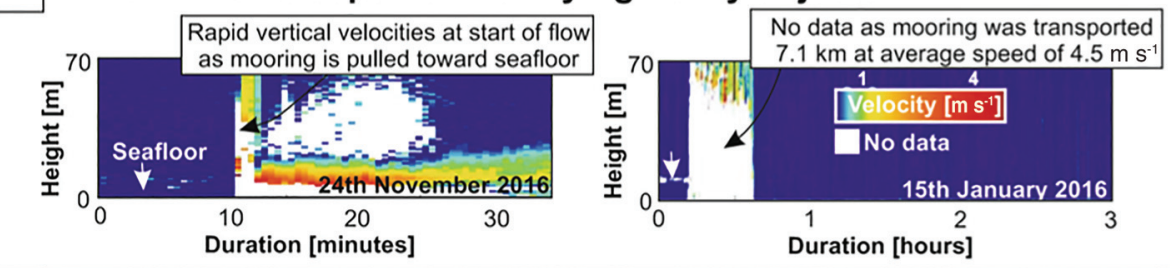

(d) Dynamic seafloor conditions
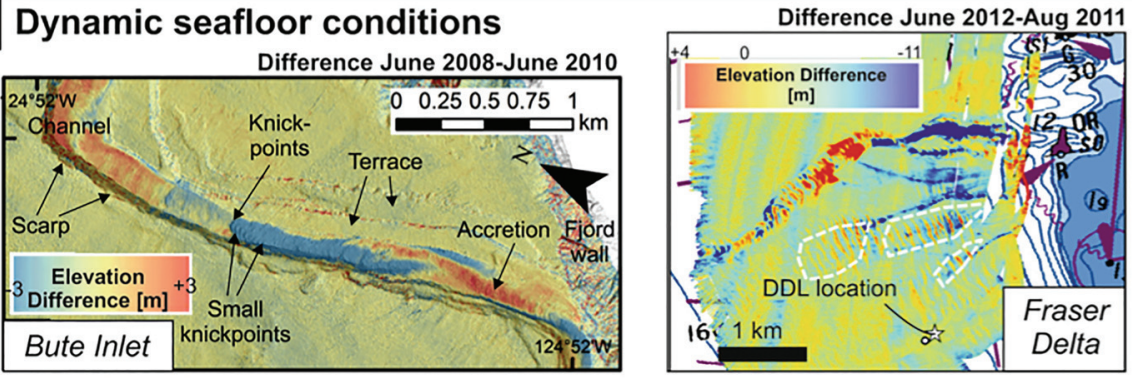

Fig. 8. (a) Overview of some of the issues encountered in monitoring active turbidity currents discussed in this paper. (b) An example of one of the long-duration turbidity currents measured in the deep-water Congo Canyon that may attain thicknesses of $>80 \mathrm{~m}$ (modified from Azpiroz-Zabala et al. 2017a). (c) Two turbidity current events measured at the shallowest water mooring in the Monterey coordinated canyon experiment in Monterey Canyon. On the left is a flow that pulled the instruments and buoyancy towards the seafloor at the start of the event due to enhanced drag early on. On the right is the record from an ADCP that was transported by a flow at several $\mathrm{m} \mathrm{s}^{-1}$; hence, no reliable data were recorded during the flow. This mooring was transported $7.1 \mathrm{~km}$ down-canyon and then broke free from its anchor and was released to the sea surface. (d) Repeat multibeam echo-sounder seafloor surveys illustrating how active turbidity currents can both erode and deposit at the seafloor. The location of the Delta Dynamics Laboratory is labelled on the Fraser Delta (right). 
and are interpreted to have been denser, with the near-bed part of the flow capable of transporting gravel and cobble-sized material (Paull et al. 2018). Second, the mooring design for the Congo Canyon included heavier anchor weighting ( $c$. $2000 \mathrm{~kg}$ ), use of low-drag neutrally buoyant plasticcoated mooring line and a larger syntactic buoy housing the ADCP. This greater buoyancy ensured that the mooring line remained taut during flows (Fig. 9). Third, and perhaps most importantly, the mooring design was much simpler for the Congo Canyon measurements than in Monterey Canyon (Fig. 9). Sediment traps were not deployed, and acoustic release links were placed $(c .40-60 \mathrm{~m})$ far above the velocity maximum of the flows, in order to reduce drag on the mooring line imparted by flows. Therefore, one way to maximize the likelihood of successful monitoring is to ensure that any instruments are located above the turbidity currents that you wish to observe, which will decrease the likelihood of drag and also add weight to the mooring line. Previous successful deployments in the Var Canyon (Mediterranean) used lower frequency $(75 \mathrm{kHz})$ downward-looking ADCPs that were placed much higher $(300-350 \mathrm{~m})$ above the seafloor than the higher frequency $300-600 \mathrm{kHz}$ instruments in the Monterey and Congo canyons (Khripounoff et al. 2012). Coarser vertical resolution was accepted to ensure that the single-point moorings interacted less with turbidity currents. The Var Canyon deployments also featured ADCPs set within gimballed frames that ensure the ADCP can tilt to remain as vertical as possible. Such a situation may be unavoidable, however, if you wish to: (i) measure close to the seafloor using high frequency instruments (e.g. Hughes Clarke et al. 2012; Clare et al. 2015; Hughes Clarke 2016); (ii) sample sediments within the flow to measure vertical grain size segregation or quantify organic particulate flux (e.g. Maier et al. 2019a, b); (iii) make measurements within the flow to ground-truth other remote sensing style measurements (e.g. Azpiroz-Zabala et al. 2017a; Hage et al. 2019). Sediment traps are typically the largest item on the mooring line; hence the height of the trap above the bed may be critical. The style of sediment trap also makes a difference. McLane-type traps provide a greater cross-sectional area than the narrower Anderson-type traps.

Design anchor weight and flotation appropriately, particularly if multiple instruments are required for single-point moorings. One of the primary goals of the Monterey Canyon CCE was to estimate suspended sediment concentrations during a turbidity current using the acoustic backscatter from the downward-facing ADCP. Given that the acoustic response of the ADCP is both a function of the concentration and the grain size of the material in suspension, it was decided that an inline sediment trap was essential, even if the presence of the trap increased drag on the mooring. While it may seem intuitive that increasing the anchor weight will improve mooring stability, this is not always the case. Moorings deployed in Monterey Canyon in the early 2000s had multiple train wheels for their anchor and long mooring lines with multiple instruments attached ( $\mathrm{Xu}$ 2011). Some of these moorings were lost due to the drag exerted during turbidity currents and the mooring line parted. Conversely, a mooring has been deployed successfully at $1300 \mathrm{~m}$ water depth in the Monterey Canyon almost continuously since 2002 with minimal ballast (scrap steel) (Barry et al. 2006; Xu et al. 2013). Its light ballast makes this mooring relatively easy to move, but this also ensures that the strain on the mooring line does not reach a critical limit. Thus, one way for a mooring to survive may be to allow it to be dragged down-canyon. This philosophy is also in keeping with minimizing the amount of debris that is left behind following mooring retrieval, as it is difficult to justify leaving iron, cables and potentially fibreglass in the marine environment.

There appears to be a 'sweet spot' for mooring design that involves a compromise between minimizing drag (which may not be possible if several instruments need to be deployed within the flow height), stabilizing the mooring base with an anchor weight and maximizing buoyancy to vertically stabilize the mooring line. The design of the mooring is an iterative process, balancing available anchor weight, surface drag (and weight) from inline mooring elements and both inline and top flotation elements. The mooring design toolbox written in Matlab by Richard Dewey (Mooring Design \& Dynamics; Dewey 1999) was used in the Monterey Canyon CCE to evaluate the performance of the single-point taut-wire moorings. The program allows a user to design a surface or subsurface wire mooring and contains a large database of the physical characteristics of standard oceanographic equipment (such as dimensions, submerged weight, surface drag), and will evaluate how a mooring responds to a static flow profile (i.e. does not account for waves). It was thought that turbidity currents in Monterey Canyon did not exceed $2 \mathrm{~m} \mathrm{~s}^{-1}$ (since the most recent data derived from one-hour averages), and this value was used in the initial mooring designs. We now know this was a considerable underestimate. It is best to have contingency and overdesign. Keeping the mooring as upright as possible (increasing the inline tension) requires additional flotation (Fig. 12a), which has the additional negative effect of making the anchor 'lighter' by increasing the upward force on the anchor, thereby making the mooring more likely to move down-canyon during events. Even the type of flotation used was a 


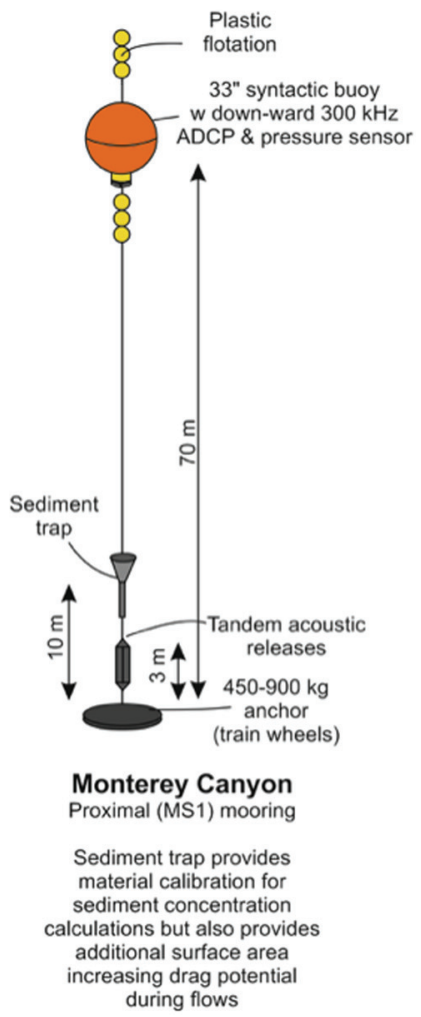

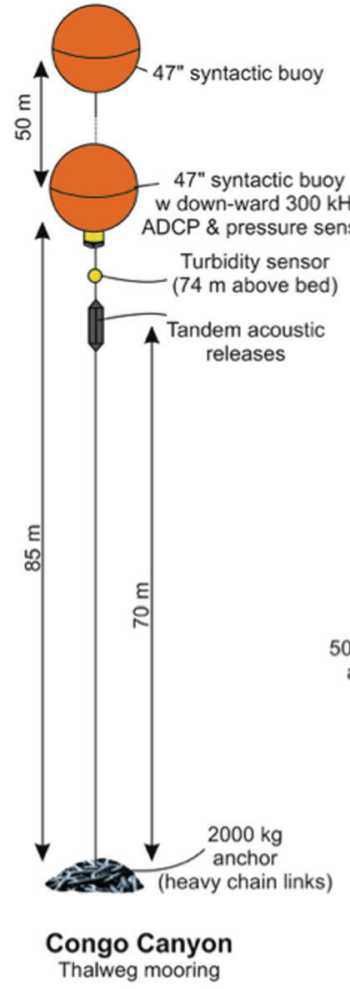

Heavy anchor and placement of acoustic releases high up on the mooring reduces drag during flows

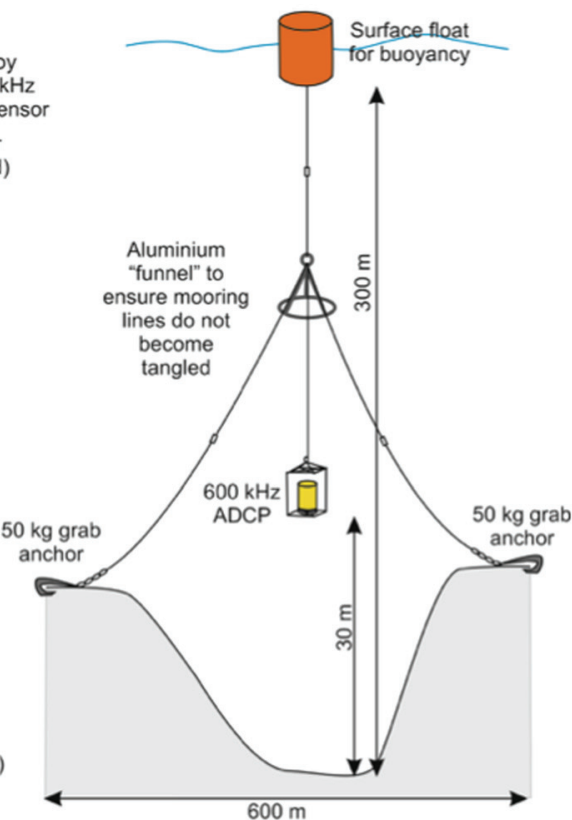

Bute Inlet

Proximal mooring

Suspended ADCP avoids direct interaction of mooring lines with flows Note: considerable vertical exaggeration

Fig. 9. Comparison of subsurface single-point moorings deployed in Monterey Canyon (Paull et al. 2018), Congo Canyon (Cooper et al. 2013; Azpiroz-Zabala et al. 2017a, b) and two-point mooring supported by a surface buoy in Bute Inlet. Not drawn fully to scale.

consideration: in shallower water (less than $800 \mathrm{~m}$ ) plastic flotation was used for inline elements to provide greater flotation per diameter of sphere (and thus surface area, because they weigh less) than comparably-sized glass or syntactic foam elements. Increasing the anchor weight from 450 to $900 \mathrm{~kg}$ and increasing the inline flotation above each sediment trap and the top of the mooring dramatically improved mooring performance, demonstrating that it is possible to refine the design successfully. This may require some a priori knowledge of the likely flow conditions. Regardless of design, one key lesson learned is to include an iridium beacon on the instrument package such that it can be tracked should it cut loose and float to the surface.

Strengthen the weak points on a monitoring platform: strategic placement of acoustic releases and resilient instrument mounting. Had the Monterey
Canyon CCE not been supported by an ROV, then the failure of the acoustic releases (placed close, $3 \mathrm{~m}$, above the seafloor) to return the moorings to the surface would have meant the loss of valuable data and instruments. Many research and industrial expeditions do not have the benefit of a support ROV; hence, we recommend that acoustic release links are placed as high as practicable above the seafloor, where they are away from the damage that may be caused at the sand-rich base of a turbidity current (but low enough such that they do not interfere with the ADCP). A recent study in the Gulf of St Lawrence (eastern Canada) by Normandeau et al. (2019a) suggested placing the acoustic release a minimum of $1 \mathrm{~m}$ above the height of intra-channel bedforms, to avoid interaction with the most vigorous and potentially dense part of the flow. Tandem acoustic release links are routinely deployed for single-point moorings (i.e. to provide redundancy 
in case one fails) but it may also be sensible to deploy the releases in series, rather than in a parallel twinned deployment so that they are not both subject to impacts at the same elevation within the flow (Xu et al. 2004).

Instrument mountings were often found to be weak points in a monitoring platform's design (e.g. Figs $3 \& 4$ ). In the case of the Monterey CCE deployments, near-bottom current meters and altimeters (10 $\mathrm{m}$ above seafloor) were mounted on protruding brackets (cantilevered) on the single-point moorings $1 \mathrm{~m}$ from the sediment trap strong-back, with one-quarter inch aluminium angle stock (instead of stainless steel, to reduce weight; Fig. 3). It was necessary to cantilever them away from the mooring in order to ensure that instruments below the ADCP were not affected by the mooring wire, or other instruments below. This design provided an even larger surface area for drag and also increased the weight on the mooring line, however, and underlines how operational necessities may end up going against the guidance to minimize drag. The aluminium design survived four turbidity currents, but eventually broke. In future, and if resources allow, we suggest that titanium should be used for mounting in similar environments. Heavy metal parts and coated iron wires should be avoided, especially for long-term deployments, as it is impossible to have a visual check on corrosion. Instead, plastic-coated ultra-high molecular weight polyethylene Dyneema rope is preferred as there are no corrosion issues, it is thin and neutrally buoyant and may be used for multiple deployments.

While it may be possible to strengthen brackets and frames, any instruments with moving external parts (e.g. the impellors that were damaged on the current meter deployed in Monterey Canyon) or that protrude away from the platform (e.g. the steel arm that held the near-bed Aquadopp in Monterey Canyon; Fig. 4) are likely to be vulnerable and should be considered to be at high risk during field deployments to measure powerful flows.

\section{Suspended monitoring systems that avoid instrument and mooring-line interaction with the flow}

To avoid the damaging effect of a passing turbidity current (e.g. drag, scour, burial), another option is to avoid placing instruments, anchors and mooring lines within the flow at all. Such an approach may also be necessary where the available support vessel for deployment cannot handle the bulky hardware (e.g. c. $1 \mathrm{~m}$ diameter syntactic buoys and stack of train wheels weighting $c .1 \mathrm{t}$ ) required for singlepoint moorings. We now discuss two plausible geometries: (i) hull-mounted systems; and (ii) surface buoy suspended systems with two or more anchors. Both of these are only practical in shallow water (typically $<500 \mathrm{~m}$ ) environments, given the amount of deck space used and the logistics involved with such quantities of mooring line and anchors, and for short-term (months) deployments. Such methods are therefore only generally applicable in fjord or lake environments and not the deep ocean; however, previous deployments in the Var Canyon has demonstrated that subsurface two-point moorings are feasible in water depths as great as $1280 \mathrm{~m}$ (Khripounoff et al. 2012).

\section{Vessel-mounted monitoring systems}

Hull-mounted deployments. Hull-mounted systems include acoustic imaging (downward-looking single or multibeam sonars or ADCP) and rapidly descending underway physical probes (e.g. Moving Vessel Profiler, MVP; Hughes Clarke et al. 1996). For any of the sonar systems, the issue becomes resolution - the further away from the seafloor, the poorer the range resolution usually is (longer, narrow-band pulses required); especially angular resolution. For single-beam sonars the width of the projected beam (typically $7-30^{\circ}$ ) may result in echoes from offset roughness elements (like bedform crests or channel flanks), which can be confused with the real near-seafloor profile. Multibeam systems (with beam widths in the $1-2^{\circ}$ range) provide far better definition (see Fig. 10a-c; Hatcher 2017). For ADCPs, just as with the conventional downward-looking single-point moorings, the closest usable data to the seabed are limited by the first echo of the projected side lobes from the beams inclined at $20^{\circ}$ (Fig. 12b). This limits the first usable bin to about $10 \%$ of the ADCP altitude (using conventional 4-beam systems). Thus, to investigate $5 \mathrm{~m}$ thick flows for example, surface-mounted ADCPs would not be of use at elevations much greater than $c .50 \mathrm{~m}$, plus the vessel has to be present at the time of the flow.

Therefore, this surface-mounted method is only viable if the flows are known to be frequent and/or of known likely timing. This was the case for the Squamish 2011-13 and 2015 campaigns (Hughes Clarke 2016). Here, a small vessel (CSL Heron) deployed an MVP. The MVP consisted of a tow body with a conductivity, temperature and depth (CTD) and an optical backscatter probe that can be released at slow speeds ( $<6$ knots). If the vessel slowed down for the descent duration (typically $2 \mathrm{~min}$ ), the probe descended to a depth of $100 \mathrm{~m}$. The MVP was deployed daily along the main channel sections to catch evidence of suspended sediment clouds due to a passing turbidity current. On a few occasions, the MVP was able to sample the top of an active turbidity current, which was also observed in the EM710 water column imagery $\left(1 \times 2^{\circ}\right.$ beam, 

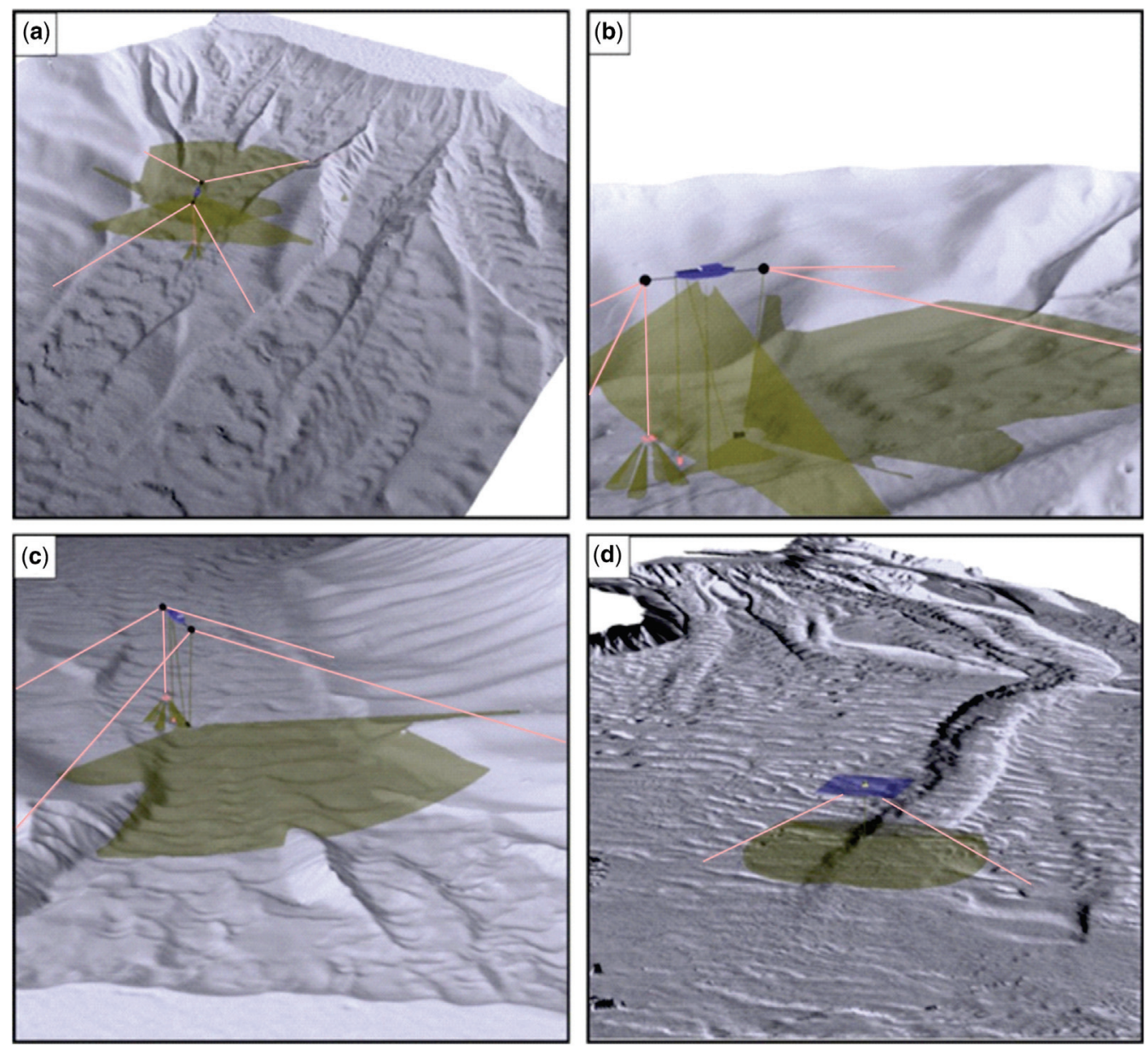

Fig. 10. Schematics illustrating Squamish experimental set-up from 2013 (a-c) and 2017-19 mooring (d). Vessel shown in blue. Acoustic imaging coverage shown in green. (a) Location of the four anchors (all located outside the active channel areas) and all acoustic imaging coverage, relative to the delta lip and prodelta channels. (b) Details of the offset surface buoys that allowed for azimuth stability of the suspended sonars. (c) View from the delta lip that was $300 \mathrm{~m}$ away, illustrating the geometry relative to the triggering mechanisms upstream. (d) Location of the channel mouth two-point anchor mooring in 2019. The water depths of the mooring were $c .160 \mathrm{~m}$ on the floor of the channel, which is about $80 \mathrm{~m}$ wide and $5 \mathrm{~m}$ deep at that point. No vertical exaggeration.

0.2 A-0.5 ms pulses, 70-100 kHz; Hughes Clarke et al. 2014; Hage et al. 2019).

The MVP has several limitations. The profile is necessarily discrete. The minimum horizontal spacing depends on the time it takes to winch back in the instrument cable, typically $5 \mathrm{~min}$ if going to $100 \mathrm{~m}$. The instrument package is deliberately designed to stop free-falling before hitting the seabed. Thus, measurements closer than $5 \mathrm{~m}$ from the actual seabed are rare and only the top of an active flow is usually recorded. The use of hullmounted instrumentation will only be useful in relatively shallow water where the recurrence of active turbidity currents is reasonably predictable. This is not the case for most turbidity current systems, where longer-term campaigns without a crew are required.

AUV-mounted deployments. Autonomous Underwater Vehicles (AUVs) now enable the acquisition of high-resolution seafloor datasets, by flying the AUV close to the seafloor (Wynn et al. 2014). These autonomous mobile systems can also hold instruments, such as ADCPs, to monitor the seafloor along transects, in the same manner as river systems are often measured (e.g. Parsons et al. 2007). A 
saline density underflow has been monitored using such an approach, to the north of the Bosphorus Strait in the Black Sea. Along- and across-channel transects of ADCP measurements were acquired using a $1200 \mathrm{kHz}$ ADCP, revealing a range of flow dynamics, which include evidence for secondary circulation cells and the presence of hydraulic jumps. These jumps had previously only been hypothesized from laboratory experiments of submarine channels (Parsons et al. 2010; Sumner et al. 2013; Wynn et al. 2014; Dorrell et al. 2016; Azpiroz-Zabala et al. 2017b). This AUV-based monitoring was also performed in a very narrow and busy shipping lane; hence surface-based monitoring would have been precluded (Wynn et al. 2014). Future developments in AUV endurance (e.g. battery performance) may make this type of monitoring more common; however, it is only likely to be used where the timing of the flow is very well constrained or continuous, as in the case of the Bosphorus underflow.

Multi-point anchoring for vessel-based monitoring. If a turbidity current is laterally restricted by canyon or channel flanks, it is possible to use two or more anchors located on either side of the channel to position a surface buoy above the active channel, from which a variety of instruments can then be suspended. In practice, there are depth limitations to this, as the longer the anchor lines, the more the suspended instrument is likely to move. The first test of the two-point anchoring method occurred in 2014 at $200 \mathrm{~m}$ water depth in Bute Inlet and then in 2015 in Squamish in 120 m of water. From 2017 to 2019, a two-point mooring was deployed in Squamish at the lobe channel termination in $160 \mathrm{~m}$ of water (Fig. 10d). A minimum of two anchors can adequately constrain the buoy across the channel, but any slack in the lines will allow the buoy to move slightly along the channel as a result of wind or tide drag on the surface buoy and the suspended lines. A third anchor helps constrain the alongchannel motion.

Four-point moorings were deployed for the 2013 Squamish experiment (Hughes Clarke 2016). This four-anchor approach not only best constrained the surface location, but also allowed the suspended instruments to be held at a fixed azimuth. For any number of anchors, if there is only a single surface buoy, the suspended instrument is free to rotate in azimuth. Thus, the instrument measurement must not be compromised by this rotation. Instruments that have an internal compass can correct for such rotations; however, any system that requires a preferred azimuth (such as the acoustic monitoring of a fixed stretch of channel by forward-looking multibeam (M3) imaging used in the 2013 and 2015 Squamish experiments; Hughes Clarke 2016; Hage et al. 2018) would not be usable. To overcome this problem, in the 2013 Squamish experiment, the four anchors were arranged in pairs to come up to two surface buoys located offset along the channel below. The surface buoys were in turn held together by a surface line. The vessel tied up daily between the two buoys and azimuth-sensitive instruments (the M3 sonars described in Hughes Clarke 2016) were suspended on a frame that was attached fore aft so that it could not rotate significantly in azimuth. Such a deployment is only suited to short-term (days to weeks) duration.

Two-point moorings for autonomous deployments. In 2016, and again in 2018, two-point moorings were deployed in water depths of up to $450 \mathrm{~m}$ in Bute Inlet (Fig. 9). Such a mooring design was conceived to remove any drag on the instruments or mooring line and because previous repeat seafloor surveys indicated that turbidity currents may be capable of depositing and eroding up to tens of metres of sediment (Conway et al. 2012; Gales et al. 2019). In this example, the anchor lines no longer connected to the surface float, but instead to a triangular frame that was suspended at about half the water depth from the surface float (Figs 9, 11c, d). This set-up reduces the length of the anchor lines, limiting the movement of the instrument and facilitating the deployment. With the submerged frame at half the water depth, the anchors can be placed one at a time and the anchor can be dropped with slight tension in the line at the final anchor location. Each anchor and chain had a weight of $100 \mathrm{~kg}$, while the surface float carrying the instruments had a buoyancy of $150 \mathrm{~kg}$. The anchor lines were about $300 \mathrm{~m}$ to keep the anchors well away from the $200 \mathrm{~m}$ wide channel (Fig. 9). Such a deployment is logistically challenging, particularly on smaller vessels, and is therefore unlikely to become a routine mooring configuration. The use of a surface buoy would also be impractical in high latitude settings where seasonal sea ice forms. A completely submerged two-point mooring was deployed in the deep-sea Var Canyon, however, which involved anchoring either side of the canyon in a water depth of $1200 \mathrm{~m}$ (Khripounoff et al. 2012). Acoustic releases were placed $10 \mathrm{~m}$ above the anchor on each of the mooring lines, so that only $10 \mathrm{~m}$ lengths of rope and anchors were left on the seafloor following retrieval. Large quantities of mooring lines, buoyancy and anchors meant that this mooring required a spacious back deck of a large ocean-going vessel.

Decision on instrument elevation for multi-point moorings. A two-point mooring with a surface buoy will only fix the elevation of the ADCP with respect to the surface. Any tidal excursions will result in the ADCP moving toward and away from the seabed. Deciding on the optimal height may 

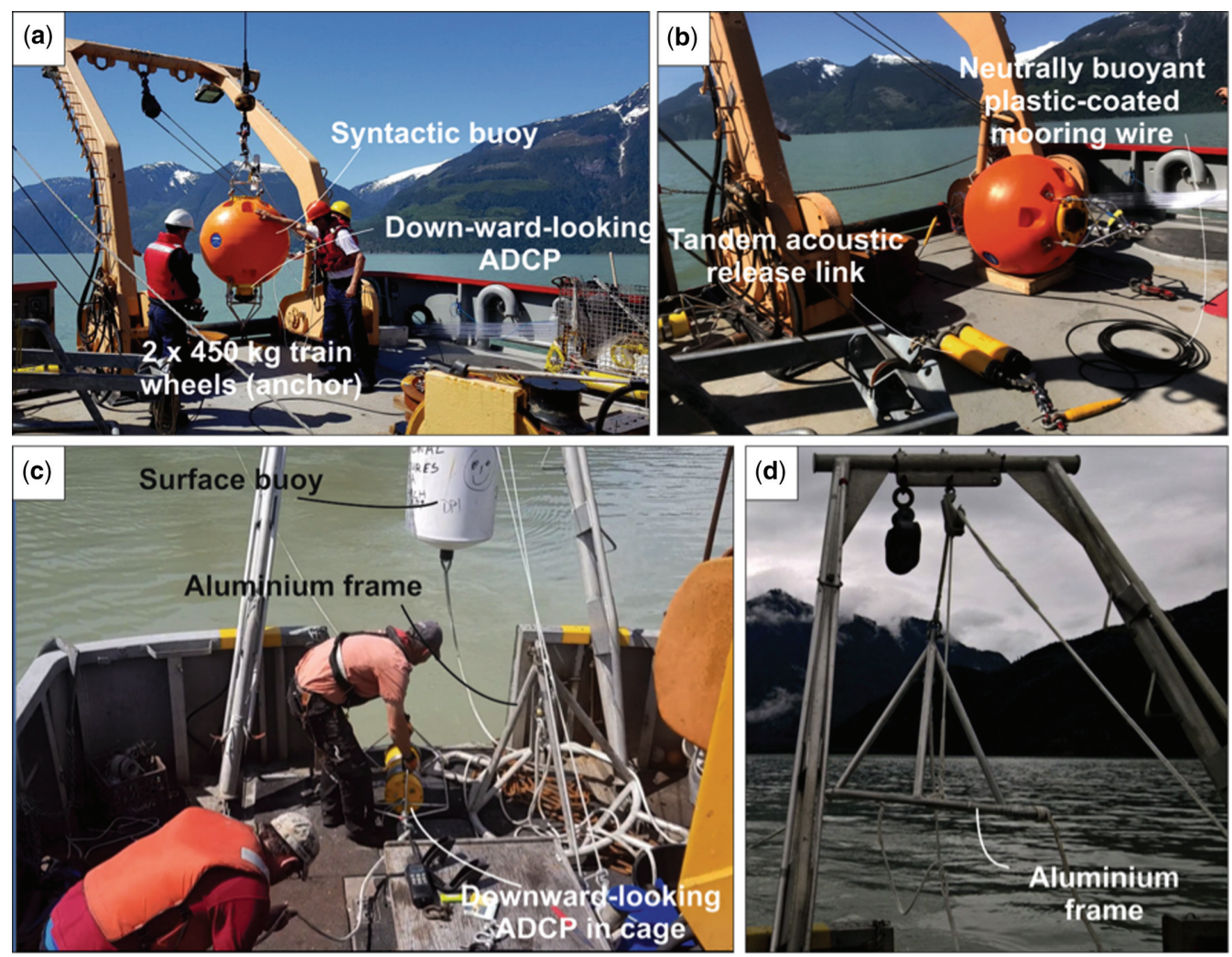

Fig. 11. Photographs comparing the typical hardware for single-point moorings (a) and (b) with hardware required for two-point moorings (c) and (d). Not shown are the $50 \mathrm{~kg}$ grab anchors used to secure each of the lines for two-point moorings.

require prior information on the likely thickness of the flows. The instrument should be above the active flow, even if partly in the turbid cloud of the wake, but at the same time, as close to the seabed as possible so that side lobe masking is minimized (Fig. 12b). In larger systems and deeper canyons, where the anchors for a two-point mooring are designed to be above the height of the flow (e.g. due to their location on canyon terraces), the ADCP will be at a considerable height above the seafloor; out of the range of high frequency instruments such as 300 or $600 \mathrm{kHz}$ ADCPs (Table 2). A twopoint mooring configuration in the Var Canyon enabled the first monitoring of powerful turbidity currents and a debris flow, with thicknesses sometimes in excess of $100 \mathrm{~m}$ (Khripounoff et al. 2012). At this height a $75 \mathrm{kHz}$ ADCP, placed $>300 \mathrm{~m}$ above the seafloor, was necessary to have sufficient range to capture this flow (Table 2).

For narrow channels, the greater the height, the higher the likelihood that one of the four ADCP beams will impinge on the channel flanks and thereby obscure details in the lower layers. In Squamish, the ADPC height varied from 10 to $15 \mathrm{~m}$ above the seabed at low tide as the high shear part of the flows is significantly thinner than this. This is compounded by the fact that turbidity currents are most likely at low tides (4 $\mathrm{m}$ range) at Squamish when elevation is lowest (Hughes Clarke et al. 2012; Clare et al. 2016; Hage et al. 2019). In Bute Inlet, the ADCP height was set at about $20 \mathrm{~m}$ above the channel base. The distance to the seafloor strongly varied depending on the tide, and data from a local tide gauge had to be used to extract the tidal signature from the data. These issues should clearly be borne in mind in tide-affected (particularly macro-tidal) settings.

An unexpected phenomenon has been noted twice when ADCPs were suspended above a turbidity current: the instrument package has been 'sucked down' into the flow. As the surface buoy only has an excess of about $50 \mathrm{~kg}$ of flotation, it appears that the highest velocity flows have enough turbulence to drag the ADCP frame down-stream, and end up 


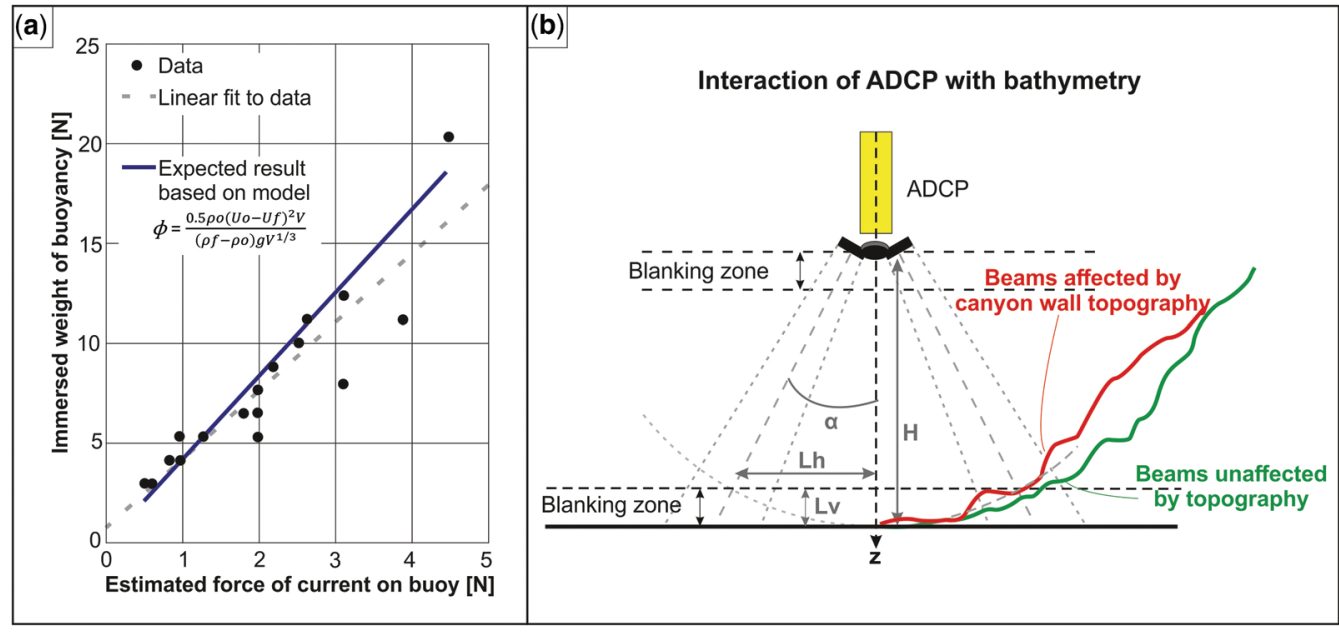

Fig. 12. (a) Laboratory test of a theoretical model to determine the force of current exerted on different weights of buoyancy. (b) Schematic to show the configuration of ADCP beams, how interaction with a topographically variable seafloor may affect data quality and how the height of the ADCP affects the proximity to the seafloor at which currents can still be monitored (see also Table 2).

pulling the surface buoy underwater because of limited anchoring; thus, entraining the instrument into the flow. In 2017, the package was dragged down on to the seabed, where it sat for $30 \mathrm{~min}$ before rising. In 2019, the instrument package was dragged down and buried, this time without release. Fortunately, the flotation was visible in multibeam water column imaging (110 $\mathrm{m}$ below the surface) and could be reached with a grapple.

\section{Seafloor platforms and cabled observatories}

While there are clear benefits in the deployment of autonomous monitoring platforms, such as moorings, they currently have finite battery power and data memory (which, in turn, limit sampling frequency). To measure power, turbulence and fine structures within flows at high temporal and vertical resolution, high bandwidth data are necessary. This may be possible for moored systems when reliable methods of preconditional sampling can be developed, to record at high bandwidth only during turbidity currents; however, research is still required in this area. Experience at the Fraser Delta has demonstrated that it is possible to design a cabled seafloor observatory that is capable of withstanding powerful turbidity currents and can transmit data in real time (Lintern et al. 2019). In many settings, such as the Fraser Delta, turbidity currents occur only at certain times of the year and extreme flows may occur years apart. Capturing these events at high bandwidth and long intervals apart is impossible with battery-

Table 2. Seafloor footprints of ADCP beams for different vertical heights, assuming a $20^{\circ}$ beam angle (typical for the moorings discussed in this paper)

\begin{tabular}{lcccc}
\hline $\begin{array}{l}\text { Height above } \\
\text { seafloor, } H(\mathrm{~m})\end{array}$ & $\begin{array}{l}\text { Side lobe interference } \\
\text { zone - blanked above } \\
\text { seafloor, } L_{\mathrm{v}}(\mathrm{m})\end{array}$ & $\begin{array}{l}\text { Radius of ADCP } \\
\text { beam footprint at } \\
\text { seafloor, } L_{\mathrm{h}}(\mathrm{m})\end{array}$ & $\begin{array}{l}\text { Diameter of ADCP } \\
\text { beam footprint at } \\
\text { seafloor, } 2 \times L_{\mathrm{h}}(\mathrm{m})\end{array}$ & $\begin{array}{l}\text { Example ADCP frequency } \\
\text { as discussed in this paper }\end{array}$ \\
\hline $\begin{array}{l}18.1 \\
500\end{array}$ & $\begin{array}{c}102.6 \\
29.1\end{array}$ & $\begin{array}{c}205.2 \\
58.1\end{array}$ & $\begin{array}{l}\text { Var Canyon } 75 \mathrm{kHz} \mathrm{ADCP} \\
\text { Congo Canyon } 300 \mathrm{kHz} \\
\text { ADCP }\end{array}$ \\
70 & 4.2 & 23.9 & 47.9 & $\begin{array}{c}\text { Monterey Canyon } 300 \mathrm{kHz} \\
\text { ADCP }\end{array}$ \\
35 & 2.1 & 12.0 & 23.9 & $\begin{array}{c}\text { Bute Inlet } 600 \mathrm{kHz} \text { ADCP } \\
\text { Squamish } 1200 \mathrm{kHz} \text { ADCP }\end{array}$ \\
\hline
\end{tabular}

$L_{\mathrm{v}}$, side lobe interference zone; $L_{\mathrm{h}}$, radius of ADCP beam footprint (as illustrated in Fig. 12b). 
powered instruments. Cabled installations provide both power and the highest bandwidth to a number of instruments. Cabled instruments report live to shore; hence, event detection is possible, which might enable a response to investigate conditions shortly after the event (as was the case of Lintern et al. 2016). Due to the array of instruments on the network, the exact environmental conditions under which turbidity currents occur are well understood at the Fraser Delta (strong freshet combined with spring tides) and their onset can be reliably predicted (Lintern et al. 2019).

A large cabled observatory requires frequent servicing and with current technologies can only be laid with long-term dedicated resources. An advantage is that once in operation, a scientist can be assured that site visits and platform maintenance and improvement can be done regularly. As mentioned, cabling platforms on the seafloor is a very expensive and intensive undertaking and cannot be readily combined with other systems (unlike more mobile mooring systems). There are only a few organizations worldwide currently able to maintain such a system. Furthermore, the cables that provide power and distribute the data gathered are weak points and are susceptible to rupture by turbidity currents (Carter et al. 2014; Clare et al. 2017). Therefore, serious consideration should be given to the routing of cable paths and one should also be prepared for the cables to be severed. Currently, ROVs are used to connect cables to platforms. This extends the deployment time from perhaps as little as a few hours on station to a day or two on station, depending on tide and visibility conditions.

Design of seafloor platforms to monitor turbidity currents will necessarily be different from more conventional tripods or other frames that are designed to measure clear-water flows (e.g. Cacchione et al. 2006). Lessons learned from the Fraser Delta deployment are similar to those for single-point moorings. The design challenge is to strike a balance between reducing the surface area of the platform to reduce drag and increasing the weight of the structure or type of legs and to ensure that it is stable to withstand toppling. For instance, the final and most successful design to date at the Fraser Delta has the largest surface area and has been stabilized in other ways. Lessons learned for the deployment of seafloor platforms therefore include:

(1) heavy weight (e.g. $900 \mathrm{~kg}$ ) beneath the platform, which is released when it comes to retrieve the platform;

(2) stable design (e.g. tripod or quadrupedal frame) with legs that can penetrate into the seafloor to act as mini piled foundations. If feet or legs are likely to become embedded or buried, they should be released during retrieval. Where the feet are not removable, the solution to recovering a buried platform is not to winch the platform out of the sediment, but instead to apply tension and let the recovering ship slowly rock the platform free;

(3) where instruments need to be suspended on hanging arms, the frame should be designed such that it can be deployed at seafloor by an $\mathrm{ROV}$, to reduce the amount of deck space needed and to minimize the risk of damage during deployment;

(4) mounting of instruments should be reinforced and use lightweight, durable materials such as titanium. Various mechanisms (hinged arms, telescoping poles) may be used to extend instruments away from the platform-induced vortices, towards the upstream flow to trigger other instruments. It may be appropriate to consider housing instruments such as ADCPs or hydrophones in shrouded cages to minimize environmental noise and vibrations. The ADCPs on the Fraser Delta frame were set in a dual-axis stabilized gimbal, which righted itself and continued to measure flows, even when the platform was completely upside down.

\section{Placement of moorings and seafloor platforms}

Given the efforts to ensure that monitoring platforms can successfully withstand and measure turbidity currents, it would be unfortunate if they were not deployed in the correct location. Precise placement also remains a challenge, particularly where support from ROVs (i.e. to verify placement location or assist with re-siting) is unavailable, or is considered too time-consuming or costly. A high-quality base map is essential to ensure that the proposed target is appropriate. As the seafloor elevation and planform can vary considerably in active submarine canyons and channels (e.g. Paull et al. 2018; Gales et al. 2019; Vendettuoli et al. 2019), it is recommended that multibeam bathymetric data be acquired prior to deployment to accurately determine the water depth and seafloor relief to ensure that the proposed location is correct (e.g. the canyon thalweg has not migrated, ADCPs will not be affected by interference with canyon side walls, mooring is not placed on a canyon-wall slump, etc.).

Deployment and siting of moorings. When placing moorings in submarine canyons or channels, the desired seafloor targets are usually very small and may rely on deployment from vessels without dynamic positioning (a computer-controlled system to maintain position and heading using thrusters). Thus, the vessel may drift off location easily during the deployment. Even with dynamic positioning, 
moorings dropped from the sea surface can drift with the current or during free fall. A triangulated location is typically acquired for moorings by communicating with the acoustic releases; however, this is often inaccurate, difficult in great water depths, and can be complicated by echoes from steep-sided canyon walls or other topographic features.

Another option to determine the location of moorings is to make use of a multibeam echosounder. As long as the mooring array has a series of scattering targets (flotation spheres or instrument housings) that are separated by more than the sonar range resolution, they can usually be discerned from the natural scatterers as you pass over them. This method has been used for detecting location of moorings, as well as to image passing turbidity currents (Hughes Clarke et al. 2014) in shallow water fjord settings, and is also feasible in deeper water using the multibeam system constrained to shorter pulse lengths ( $2 \mathrm{~ms})$ in a narrow swathe. This should therefore enable identification of moorings in up to $2 \mathrm{~km}$ of water.

Where moorings are lowered to the seafloor, a position fix can be acquired from an Ultra-Short BaseLine (USBL) system. It is worth including beacons on the moorings that would allow the mooring's actual position (during deployment and monitoring periods) to be determined with the necessary accuracy; however, this technique gets increasingly expensive with greater water depths.

The effects of human interference with the seafloor should be considered when choosing a platform location, as activities such as fishing, trawling, anchor deployment and dredging can snag, displace or damage monitoring platforms. Moorings should be placed in water depths greater than the keel of icebergs in areas affected by seasonal ice cover.

Specifics on deployment of single-point moorings. Two general approaches exist for the deployment of single-point moorings. The first is to deploy the anchor last (i.e. buoyancy and mooring line with instruments attached are offloaded to sea prior to dropping the anchor at the desired location). An anchor-last deployment also allows you to manoeuvre the vessel to above the desired location using USBL and then drop the mooring once on location. This approach has been shown to achieve a precision of $\pm 10-20$ m horizontal accuracy in water depths of up to $2 \mathrm{~km}$, and $50-60 \mathrm{~m}$ at $5 \mathrm{~km}$ water depth, and depends firmly upon the vessel's captain, ship handling skills of the mate on watch, maintaining efficient communication between the deck, bridge and science crew, and fair weather conditions and sea state at the time of deployment. The second is to deploy the anchor first, which can be hazardous as the mooring line will be in tension on the back deck of the vessel. For this reason, in particular, an anchor-first strategy is precluded when heavy anchors are required (due to very high line tensions).

Deployment of two-point moorings. In shallow water, where the line suspending the instrument and anchor lines are all connected to a surface buoy, anchors for two-point moorings can first be placed individually. After the anchors are placed with a small surface float, then the anchor lines can be connected to a single point above the channel and the instrument can be lowered from this central surface buoy. In deeper water, the use of submerged frames is more appropriate (given the length of mooring lines required). Two deployment methods have been successful in safely placing these deeperwater two-point moorings. In the first method, the instrument is lowered above the channel, followed by the frame, and roughly kept in place by a small boat. While the small boat holds on to the second anchor line, a larger ship (with winch and Aframe) sets off with the first anchor line. On the larger boat, the anchor line is connected to the chain and anchor before being dropped at the anchor location. Then the larger ship returns to the smaller boat to pick up the second anchor line and drop the second anchor.

A second approach, that has also been successfully applied, involves releasing the central part of the mooring down in one step. For this approach, all the lines, the instrument, the frame and the float need to be carefully laid out on the back deck. The procedure starts by deploying the first anchor and laying out the anchor line, while the ship slowly steams from the first anchor position towards the channel. Just before reaching the channel, the instrument is lowered into the water with a line tied to the submerged frame that is hanging from the A-frame of the ship. As the boat crosses the channel, the first anchor line starts to tighten and the submerged frame is dropped in the water. While the boat keeps steaming slowly towards the second anchor position, the second anchor line and the line connecting the submerged frame to the surface buoy are slowly released. As the line towards the buoy runs out, the buoy is released from the ship. Finally, when the boat reaches the second anchor position the last anchor is dropped. The advantage of the first method is that the deployment is done step by step and is more controlled; however, it requires two vessels and there is a higher chance for the instrument and second anchor line to become tangled during the deployment of the first anchor. The second method requires only one vessel, but needs a larger back deck (and very careful preparations), as the lines are dragged behind the ship and its propeller, the ship will have to continue moving forwards to prevent the lines from tangling in the propeller. So, in the second approach everything needs to be 
deployed in one go; once the first anchor is dropped there is no way back. Both methods have been used in Bute Inlet four times and all moorings have been placed successfully. Retrieving these two-point moorings is fairly straightforward. After picking up the surface buoy the line is connected to the winch and the whole mooring is pulled out. A $1 \mathrm{t}$ winch has always been successful in retrieving the moorings, although we have had to cut one anchor line, possibly as a result of a buried anchor. Depending on the type of anchor and the angle of the anchor lines, larger forces could be applied to the submerged frame, so it might be advisable to make sure that the link between the anchor lines and the frame are the weakest connection in the mooring, to ensure that the instrument is always recovered. Alternatively, acoustic release links could be incorporated into the mooring design (i.e. one on each mooring line); however, these would add additional weight to the mooring line, which would need to be considered.

\section{Conclusions and final thoughts}

The design of monitoring platforms needs to deal with high velocities and sediment concentrations close to the seafloor, capable of tilting, displacing, transporting and even damaging instruments. Our experience shows that, despite the challenges posed, it is possible to make detailed measurements of powerful sediment-laden flows. These challenges can be overcome by simplifying single-point mooring design to reduce drag potential, or deploying two-point moorings (or from vessels), where neither mooring lines nor instruments interact with the flow itself (Fig. 13). Where it is necessary to deploy

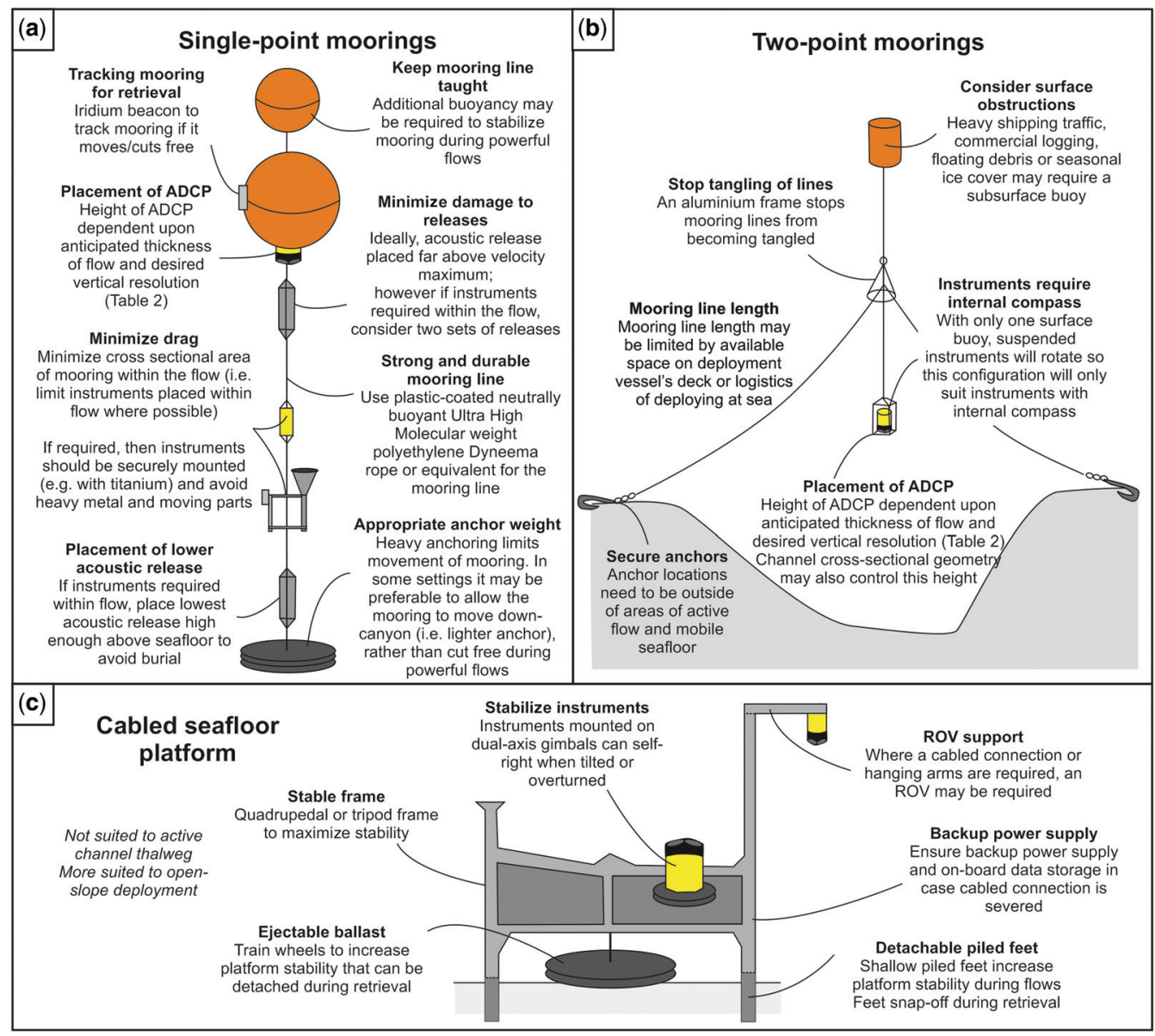

Fig. 13. Summary of lessons learned for designing monitoring platforms, illustrating key considerations when measuring powerful turbidity currents for: (a) single-point moorings; (b) two-point moorings; and (c) cabled seafloor platforms. 
Table 3. Summary of considerations for different types of turbidity current monitoring platforms

\begin{tabular}{|c|c|c|c|}
\hline Platform type & Environment & Benefits & Considerations \\
\hline $\begin{array}{l}\text { Single-point } \\
\text { mooring }\end{array}$ & $\begin{array}{l}\text { Long-term deployment } \\
\text { in canyon/channel } \\
\text { thalweg or unconfined } \\
\text { slope }\end{array}$ & $\begin{array}{l}\text { - Simple mooring design } \\
\text { - Relatively easy to deploy } \\
\text { - Simple retrieval using } \\
\text { acoustic release link and } \\
\text { sacrificial anchor weight }\end{array}$ & $\begin{array}{l}\text { As it interacts with the flow, } \\
\text { mooring may need to be } \\
\text { designed to cope with } \\
\text { downslope transport or maintain } \\
\text { taut line (large anchor weight } \\
\text { and high buoyancy) } \\
\text { - Ideally, reduce drag by } \\
\text { minimizing cross-sectional area } \\
\text { (e.g. reducing instruments) on } \\
\text { mooring line } \\
\text { Acoustic releases should be } \\
\text { placed above velocity maximum } \\
\text { of flow; however, if instruments } \\
\text { are required within the flow, } \\
\text { then releases should be placed } \\
\text { below those instruments and } \\
\text { also above } \\
\text { Large ocean-going vessel may } \\
\text { be required to deploy heavy } \\
\text { anchor weights and buoyancy }\end{array}$ \\
\hline $\begin{array}{l}\text { Two-point } \\
\text { mooring }\end{array}$ & $\begin{array}{l}\text { Short-term deployment } \\
\text { over channels/ } \\
\text { canyons } \\
\text { Particularly useful } \\
\text { where flows are } \\
\text { highly erosive or have } \\
\text { dense near-bed layer }\end{array}$ & $\begin{array}{l}\text { - None of mooring interacts } \\
\text { with flow } \\
\text { - Unaffected if erosion or } \\
\text { deposition affect seafloor }\end{array}$ & $\begin{array}{l}\text { - Challenging field deployment } \\
\text { requiring considerable lengths of } \\
\text { mooring line } \\
\text { - Requires larger vessel for } \\
\text { retrieval of anchors and } \\
\text { mooring lines } \\
\text { - Only possible where stable } \\
\text { terraces, levees or channel } \\
\text { margin permit anchor placement } \\
\text { - Surface buoy may pose a } \\
\text { problem in areas with seasonal } \\
\text { ice cover, busy shipping } \\
\text { or logging }\end{array}$ \\
\hline $\begin{array}{l}\text { Vessel-mounted } \\
\text { mooring }\end{array}$ & $\begin{array}{l}\text { Shallow-water settings } \\
\text { where timing of } \\
\text { turbidity currents is } \\
\text { known }\end{array}$ & $\begin{array}{l}\text { - None of mooring interacts } \\
\text { with flow } \\
\text { - Continuous power } \\
\text { to instruments } \\
\text { - Possible to adjust } \\
\text { instrument settings and } \\
\text { acquire calibration samples } \\
\text { in real-time }\end{array}$ & $\begin{array}{l}\text { Only suitable for shallow } \\
\text { water settings } \\
\text { - Requires vessel with crew; } \\
\text { hence, only suitable for } \\
\text { relatively short deployments }\end{array}$ \\
\hline Benthic lander & $\begin{array}{l}\text { Unconfined slope and/ } \\
\text { or dilute flows }\end{array}$ & $\begin{array}{l}\text { - Continuous data } \\
\text { transmission, enabling } \\
\text { near-real time response } \\
\text { (e.g. to perform seafloor } \\
\text { survey) } \\
\text { - Externally powered, } \\
\text { allowing for multiple } \\
\text { instruments recording at } \\
\text { high frequency }\end{array}$ & $\begin{array}{l}\text { - Not suitable for placement in } \\
\text { active canyon/channel thalweg } \\
\text { - May be buried, or undermined } \\
\text { by erosion } \\
\text { - To withstand powerful flows, } \\
\text { requires ballast that can be } \\
\text { ejected and removable feet } \\
\text { - Requires support ROV during } \\
\text { deployment if cabled links or } \\
\text { additional instruments need to } \\
\text { be added once platform is } \\
\text { on seafloor }\end{array}$ \\
\hline
\end{tabular}


instruments within the flow, it may not be possible to reduce drag, hence additional stability is essential, such as extra buoyancy and anchoring for singlepoint moorings, or piled legs and extra weight for seafloor platforms (Fig. 13). Instrument mounting may be a weak point in such designs; hence brackets and cages should be more robust than standard moorings (see Fig. 13) Table 3 provides a summary of these considerations and scenarios that are most suitable for different monitoring platforms.

There is currently a push to develop nextgeneration monitoring tools to detect and characterize turbidity currents, relying upon passive detection, rather than direct measurements (e.g. Clare et al. 2017; Lintern et al. 2019). Such tools include hydrophones and geophones and will enable measurement of turbidity currents and other submarine mass movements, without the need to place moorings or platforms in the path of the flow (particularly where the flow is restricted to channels (Chadwick et al. 2012; Caplan-Auerbach et al. 2014). This approach requires calibration against ADCPs and other measurements and the initial results are promising. There is clear evidence that acoustic signals can be linked to independently measured turbidity currents (Hatcher 2017; Lintern et al. 2019). In addition to measuring transit speeds via arrival times, there is potential to measure some basic features of flow character using hydrophones. For example, the intensity of acoustic signals may be related to internal flow speeds (via intensity of grain collisions), grain size (sand- or mud-dominated flow) or the presence of a dense and coarse near-bed layer. However, further work would be needed to determine what is possible and how flows should be recorded. Other developments in distributed sensing along fibre-optic cables also demonstrate the potential utility of cabled submarine links, such as those that connect the Fraser DDL to the VENUS seafloor cabled network, to measure strain, temperature and to use the optical fibres as distributed acoustic sensors (e.g. Lindsey et al. 2017, 2019; Hartog et al. 2018).

Finally, there is growing interest in monitoring a wider range of deep-sea sediment transport processes, including the influence of internal tides (Maier et al. 2019b), thermohaline-driven circulation (Miramontes et al. 2019) and the mixed interaction of downslope gravity-driven flows such as turbidity currents with along-slope contour currents (Normandeau et al. 2019b; Fuhrmann et al. 2020). As such flows are typically of lower velocity (generally $<<1 \mathrm{~m} \mathrm{~s}^{-1}$; McCave et al. 2017) and comprise lower sediment concentrations than turbidity currents, they should be considerably more straightforward to measure. Therefore, many of the issues outlined in this study are unlikely to be a major issue; however, the lessons learned should still be considered - such as minimizing drag and maintaining stability of the platform to ensure that high-quality results are acquired. Burial risk may be greater in areas of high net deposition. To date, limited near-bed measurements of contour currents have been made and none are yet known from mixed turbidity current-contour current systems. Therefore, there is a need for instruments to be placed closer to the seafloor in such systems to fill this knowledge gap. Such systems are also typically much more laterally extensive than 'conventional' turbidity current canyons or channels; hence, it will be necessary to deploy an array of monitoring platforms to characterize the spatial variability in near-bed flow that may be strongly controlled by local variations in seafloor morphology.

We conclude that recent and ongoing advances in technology and mooring design will ensure that key knowledge gaps in turbidity current behaviour can soon be filled, providing valuable information for designing resilient seafloor infrastructure, and understanding of how and when these globally important processes transport sediment, nutrients and organic carbon to the deep sea.

Acknowledgements This study is based on fieldwork and logistical support provided by a large number of people, including: (i) the Monterey Coordinated Canyon Experiment (CCE) Team; (ii) Bute Inlet 2016 and 2018 teams; (iii) Squamish 2015 monitoring team; and most notably, (iv) the patient and diligent crews of the following vessels: Strickland, Heron, Vector, Rachel Carson and Dock Ricketts. Use of trademark names does not imply endorsement of products by the authors or the USGS.

Funding Clare, Cartigny and Talling acknowledge funding from the Natural Environment Research Council (NERC), including 'Environmental Risks to Infrastructure: Identifying and Filling the Gaps' (NE/ P005780/1) and 'New field-scale calibration of turbidity current impact modelling' (NE/P009190/1). The authors also acknowledge discussions with collaborators as part of Talling's NERC International Opportunities Fund grant (NE/M017540/1) 'Coordinating and pump-priming international efforts for direct monitoring of active turbidity currents at global test sites'. Talling was supported by a NERC and Royal Society Industry Fellowship hosted by the International Cable Protection Committee. Funding for the Coordinated Canyon Experiment (CCE) was provided by David and Lucile Packard Foundation, Natural Environment Research Council (grant NE/K011480/1), U.S. Geological Survey (USGS) Coastal and Marine Program, and Ocean University of China. Additional funding for MAC was provided by NERC National Capability Climate Linked Atlantic Sector Science Programme (NE/R015953/1).

Author contributions MC: conceptualization (lead), formal analysis (equal), funding acquisition (equal), investigation (lead), methodology (equal), project 
administration (equal), visualization (lead), writing original draft (lead), writing - review \& editing (lead); DGL: conceptualization (equal), formal analysis (supporting), investigation (equal), methodology (equal), resources (equal), writing - review \& editing (supporting); KR: formal analysis (equal), investigation (equal), methodology (equal), project administration (supporting), writing - original draft (supporting), writing - review \& editing (supporting); JEHC: conceptualization (equal), formal analysis (supporting), investigation (equal), methodology (equal), writing original draft (supporting), writing - review \& editing (supporting); CP: conceptualization (equal), formal analysis (supporting), funding acquisition (equal), investigation (equal), methodology (equal), project administration (equal), writing - original draft (supporting), writing - review \& editing (supporting); RG: formal analysis (supporting), investigation (supporting), methodology (supporting), writing original draft (supporting); MJBC: conceptualization (supporting), formal analysis (supporting), investigation (equal), methodology (equal), project administration (equal), writing - original draft (supporting), writing review \& editing (supporting); PJT: conceptualization (supporting), funding acquisition (equal), investigation (equal), methodology (supporting), resources (equal), writing - review \& editing (supporting); DPe: conceptualization (supporting), formal analysis (supporting), investigation (supporting); JX: funding acquisition (supporting), methodology (supporting), project administration (supporting), writing - original draft (supporting); DPa: conceptualization (supporting), investigation (supporting), methodology (supporting), project administration (supporting); RSJ: conceptualization (supporting), methodology (supporting), writing - original draft (supporting), writing - review \& editing (supporting); RA: methodology (supporting), writing - review \& editing (supporting).

\section{References}

Ayranci, K., Lintern, D.G., Hill, P.R. and Dashtgard, S.E. 2012. Tide-supported gravity flows on the upper delta front, Fraser River delta, Canada. Marine Geology, 326, 166-170, https://doi.org/10.1016/j.margeo. 2012.09.007

Azpiroz-Zabala, M., Cartigny, M.J. et al. 2017a. Newly recognized turbidity current structure can explain prolonged flushing of submarine canyons. Science Advances, 3, e1700200, https://doi.org/10.1126/ sciadv. 1700200

Azpiroz-Zabala, M., Cartigny, M.J., Sumner, E.J., Clare, M.A., Talling, P.J., Parsons, D.R. and Cooper, C. $2017 b$. A general model for the helical structure of geophysical flows in channel bends. Geophysical Research Letters, 44, 11-932, https://doi.org/10. 1002/2017GL075721

Babonneau, N., Savoye, B., Cremer, M. and Bez, M. 2010. Sedimentary architecture in meanders of a submarine channel: detailed study of the present Congo turbidite channel (Zaiango project). Journal of Sedimentary Research, 80, 852-866, https://doi.org/10.2110/jsr. 2010.078
Barry, J.P., Paull, C.K., Xu, J.P., Buck, K.R., Whaling, P., Ussler, W., III and Caress, D. 2006. The tempo and intensity of turbidity flows in Monterey Canyon. AGU Ocean Sciences Meeting, 20-24 February 2006, Honolulu, Hawaii.

Best, T.C. and Griggs, G.B. 1991. The Santa Cruz littoral cell: difficulties in quantifying a coastal sediment budget. In: Coastal Sediments. American Society of Civil Engineers, 2262-2276.

Bornhold, B.D., Ren, P. and Prior, D.B. 1994. Highfrequency turbidity currents in British Columbia fjords. Geo-Marine Letters, 14, 238-243, https://doi.org/10. $1007 / B F 01274059$

Bruschi, R., Bughi, S., Spinazzè, M., Torselletti, E. and Vitali, L. 2006. Impact of debris flows and turbidity currents on seafloor structures. Norwegian Journal of Geology/Norsk Geologisk Forening, 86, 317-336.

Burnett, D.R. and Carter, L. 2017. International submarine cables and biodiversity of areas beyond national jurisdiction: the cloud beneath the sea. Brill Research Perspectives in the Law of the Sea, 1, 1-72, https://doi. org/10.1163/24519359-12340002

Cacchione, D.A., Sternberg, R.W. and Ogston, A.S. 2006. Bottom instrumented tripods: history, applications, and impacts. Continental Shelf Research, 26, 2319-2334, https://doi.org/10.1016/j.csr.2006.07.027

Caplan-Auerbach, J., Dziak, R.P., Bohnenstiehl, D.R., Chadwick, W.W. and Lau, T.K. 2014. Hydroacoustic investigation of submarine landslides at West Mata volcano, Lau Basin. Geophysical Research Letters, 41, 5927-5934, https://doi.org/10.1002/2014GL0 60964

Carter, L. 2010. Submarine Cables and the Oceans. Connecting the World, 31. UNEP/Earthprint.

Carter, L., Gavey, R., Talling, P.J. and Liu, J.T. 2014. Insights into submarine geohazards from breaks in subsea telecommunication cables. Oceanography, 27, 58-67, https://doi.org/10.5670/oceanog.2014.40

Chadwick, W.W., Jr, Dziak, R.P., Haxel, J.H., Embley, R.W. and Matsumoto, H. 2012. Submarine landslide triggered by volcanic eruption recorded by in situ hydrophone. Geology, 40, 51-54, https://doi.org/10. 1130/G32495.1

Clare, M.A., Cartigny, M.J.B. et al. 2015. Quantification of near-bed dense layers and implications for seafloor structures: new insights into the most hazardous aspects of turbidity currents. Offshore Technology Conference, https://doi.org/10.4043/25705-MS

Clare, M.A., Clarke, J.H., Talling, P.J., Cartigny, M.J. and Pratomo, D.G. 2016. Preconditioning and triggering of offshore slope failures and turbidity currents revealed by most detailed monitoring yet at a fjord-head delta. Earth and Planetary Science Letters, 450, 208-220, https://doi.org/10.1016/j.eps1.2016.06.021

Clare, M.A., Vardy, M.E. et al. 2017. Direct monitoring of active geohazards: emerging geophysical tools for deep-water assessments. Near Surface Geophysics, 15, 427-444, https://doi.org/10.3997/1873-0604. 2017033

Conway, K.W., Barrie, J.V., Picard, K. and Bornhold, B.D. 2012. Submarine channel evolution: active channels in fjords, British Columbia, Canada. Geo-Marine Letters, 32, 301-312, https://doi.org/10.1007/s00367-0120280-4 
Cooper, C.K., Andrieux, O. and Wood, J. 2013. Turbidity current measurements in the Congo Canyon. Offshore Technology Conference, https://doi.org/10.4043/ 23992-MS

Cooper, C., Wood, J. et al. 2016. Designing for turbidity currents in the Congo Canyon. Offshore Technology Conference, https://doi.org/10.4043/26919-MS

de Stigter, H.C., Boer, W., de Jesus Mendes, P.A., Jesus, C.C., Thomsen, L., van den Bergh, G.D. and van Weering, T.C. 2007. Recent sediment transport and deposition in the Nazaré Canyon, Portuguese continental margin. Marine Geology, 246, 144-164, https://doi. org/10.1016/j.margeo.2007.04.011

Dengler, A.T., Wilde, P., Noda, E.K. and Normark, W.R. 1984. Turbidity currents generated by Hurricane Iwa. Geo-Marine Letters, 4, 5-11, https://doi.org/10. 1007/BF02237967

Dewey, R.K. 1999. Mooring Design \& Dynamics - a Matlab® package for designing and analyzing oceanographic moorings. Marine Models, 1, 103-157, https:// doi.org/10.1016/S1369-9350(00)00002-X

Dorrell, R.M., Peakall, J. et al. 2016. Flow dynamics and mixing processes in hydraulic jump arrays: implications for channel-lobe transition zones. Marine Geology, 381, 181-193, https://doi.org/10.1016/j.margeo.2016. 09.009

El-Robrini, M., Gennesseaux, M. and Mauffret, A. 1985. Consequences of the El-Asnam earthquakes: turbidity currents and slumps on the Algerian margin (Western Mediterranean). Geo-Marine Letters, 5, 171-176, https://doi.org/10.1007/BF02281635

Fildani, A. 2017. Submarine Canyons: a brief review looking forward. Geology, 45, 383-384, https://doi.org/ 10.1130/focus042017.1

Fuhrmann, A., Kane, I.A., Clare, M.A., Ferguson, R.A., Schomacker, E., Bonamini, E. and Contreras, F.A. 2020. Hybrid turbidite-drift channel complexes: An integrated multiscale model. Geology, https://doi. org/10.1130/G47179.1

Gales, J.A., Talling, P.J., Cartigny, M.J., Hughes Clarke, J., Lintern, G., Stacey, C. and Clare, M.A. 2019. What controls submarine channel development and the morphology of deltas entering deep-water fjords? Earth Surface Processes and Landforms, 44, 535-551, https://doi.org/10.1002/esp.4515

Gennesseaux, M., Guibout, P. and Lacombe, H. 1971. Enregistrement de courants de turbidité dans la vallée sous-marine du Var (Alpes-Maritimes). Comptes Rendus de l'Academie des Sciences Paris, 273, 2456-2459.

Hage, S., Cartigny, M.J. et al. 2018. How to recognize crescentic bedforms formed by supercritical turbidity currents in the geologic record: insights from active submarine channels. Geology, 46, 563-566, https:// doi.org/10.1130/G40095.1

Hage, S., Cartigny, M.J. et al. 2019. Direct monitoring reveals initiation of turbidity currents from extremely dilute river plumes. Geophysical Research Letters, 46, 11310-11320, https://doi.org/10.1029/2019GL 084526

Hartog, A.H., Belal, M. and Clare, M.A. 2018. Advances in distributed fiber-optic sensing for monitoring marine infrastructure, measuring the deep ocean, and quantifying the risks posed by seafloor hazards. Marine
Technology Society Journal, 52, 58-73, https://doi. org/10.4031/MTSJ.52.5.7

Hatcher, M.G. 2017. Ambient Noise from Turbidity Currents in Howe Sound. MSc thesis, Dalhousie University, http://hdl.handle.net/10222/73224

Hay, A.E. 1987a. Turbidity currents and submarine channel formation in Rupert Inlet, British Columbia: 1. Surge observations. Journal of Geophysical Research: Oceans, 92, 2875-2881, https://doi.org/10.1029/ JC092iC03p02875

Hay, A.E. $1987 b$. Turbidity currents and submarine channel formation in Rupert Inlet, British Columbia: 2. The roles of continuous and surge-type flow. Journal of Geophysical Research: Oceans, 92, 2883-2900, https://doi.org/10.1029/JC092iC03p02883

Hay, A.E., Burling, R.W. and Murray, J.W. 1982. Remote acoustic detection of a turbidity current surge. Science, 217, 833-835, https://doi.org/10.1126/science.217. 4562.833

Heerema, C., Talling, P.J. et al. 2020. What determines the downstream evolution of turbidity currents? Earth and Planetary Science Letters, 532, 116023, https://doi. org/10.1016/j.epsl.2019.116023

Heezen, B.C. and Ewing, W.M. 1952. Turbidity currents and submarine slumps, and the 1929 Grand Banks [Newfoundland] earthquake. American Journal of Science, 250, 849-873, https://doi.org/10.2475/ajs.250. 12.849

Heezen, B.C. and Ewing, M. 1955. Orleansville earthquake and turbidity currents. AAPG Bulletin, 39, 2505-2514.

Heezen, B.C., Menzies, R.J., Schneider, E.D., Ewing, W.M. and Granelli, N.C.L. 1964. Congo submarine canyon. AAPG Bulletin, 48, 1126-1149.

Hill, P.R. 2012. Changes in submarine channel morphology and slope sedimentation patterns from repeat multibeam surveys in the Fraser River delta, western Canada. International Association of Sedimentologists, Special Publication, 44, 47-70.

Hughes Clarke, J.E. 2016. First wide-angle view of channelized turbidity currents links migrating cyclic steps to flow characteristics. Nature Communications, 7 , 11896, https://doi.org/10.1038/ncomms11896

Hughes Clarke, J.E., Mayer, L.A. and Wells, D.E. 1996. Shallow-water imaging multibeam sonars: a new tool for investigating seafloor processes in the coastal zone and on the continental shelf. Marine Geophysical Researches, 18, 607-629, https://doi.org/10.1007/ BF00313877

Hughes Clarke, J.E., Brucker, S. et al. 2012. The Squamish ProDelta: monitoring active landslides and turbidity currents. Canadian Hydrographic Conference 2012, Proceedings, Ontario, Canada, 1-15.

Hughes Clarke, J.E., Marques, C.R.V. and Pratomo, D. 2014. Imaging active mass-wasting and sediment flows on a fjord delta, Squamish, British Columbia. In: Krastel, S. et al. (eds) Submarine Mass Movements and their Consequences. Advances in Natural and Technological Hazards Research, 37. Springer, Cham, 249-260, https://doi.org/10.1007/978-3-319-00972$8 \_22$

Hsu, S.K., Kuo, J., Chung-Liang, L., Ching-Hui, T., Doo, W.B., Ku, C.Y. and Sibuet, J.C. 2008. Turbidity currents, submarine landslides and the 2006 Pingtung earthquake off SW Taiwan. TAO: Terrestrial, 
Atmospheric and Oceanic Sciences, 19, 767-772, https://doi.org/10.3319/TAO.2008.19.6.767(PT)

Inman, D.L. 1970. Strong currents in submarine canyons. Transactions of the American Geophysical Union, 51, 319.

Inman, D.L., Nordstrom, C.E. and Flick, R.E. 1976. Currents in submarine canyons: an air-sea-land interaction. Annual Review of Fluid Mechanics, 8, 275-310, https://doi.org/10.1146/annurev.fl.08. 010176.001423

Khripounoff, A., Vangriesheim, A., Babonneau, N., Crassous, P., Dennielou, B. and Savoye, B. 2003. Direct observation of intense turbidity current activity in the Zaire submarine valley at $4000 \mathrm{~m}$ water depth. Marine Geology, 194, 151-158, https://doi.org/10.1016/ S0025-3227(02)00677-1

Khripounoff, A., Vangriesheim, A., Crassous, P. and Etoubleau, J. 2009. High frequency of sediment gravity flow events in the Var submarine canyon (Mediterranean Sea). Marine Geology, 263, 1-6, https://doi.org/10. 1016/j.margeo.2009.03.014

Khripounoff, A., Crassous, P., Bue, N.L., Dennielou, B. and Jacinto, R.S. 2012. Different types of sediment gravity flows detected in the Var submarine canyon (northwestern Mediterranean Sea). Progress in Oceanography, 106, 138-153, https://doi.org/10.1016/j. pocean.2012.09.001

Krause, D.C., White, W.C., Piper, D.J.W. and Heezen, B.C. 1970. Turbidity currents and cable breaks in the western New Britain Trench. Geological Society of America Bulletin, 81, 2153-2160, https://doi.org/10.1130/ 0016-7606(1970)81[2153:TCACBI]2.0.CO;2

Kostaschuk, R.A., Luternauer, J.L., McKenna, G.T. and Moslow, T.F. 1992. Sediment transport in a submarine channel system; Fraser River delta, Canada. Journal of Sedimentary Research, 62, 273-282.

Lambert, A. and Giovanoli, F. 1988. Records of riverbome turbidity currents and indications of slope failures in the Rhone delta of Lake Geneva. Limnology and Oceanography, 33, 458-468, https://doi.org/10.4319/lo. 1988.33.3.0458

Lindsey, N.J., Martin, E.R. et al. 2017. Fiber-optic network observations of earthquake wavefields. Geophysical Research Letters, 44, 11-792, https://doi.org/10. 1002/2017GL075722

Lindsey, N., Dawe, C. and Ajo-Franklin, J. 2019. Photonic seismology in Monterey Bay: Dark fiber DAS illuminates offshore faults and coastal ocean dynamics [Preprint]. EarthArXiv, https://doi.org/10.31223/osf.io/ $7 \mathrm{bf} 92$

Lintern, D.G. and Hill, P.R. 2010. An underwater laboratory at the Fraser River delta. Eos, Transactions of the American Geophysical Union, 91, 333-334, https:// doi.org/10.1029/2010EO380001

Lintern, D.G., Hill, P.R. and Stacey, C. 2016. Powerful unconfined turbidity current captured by cabled observatory on the Fraser River delta slope, British Columbia, Canada. Sedimentology, 63, 1041-1064, https:// doi.org/10.1111/sed.12262

Lintern, D.G., Mosher, D.C. and Scherwath, M. 2019. Advancing from subaqueous mass movement case studies to providing advice and mitigation. Geological Society, London, Special Publications, 477, 1-14, https://doi.org/10.1144/SP477-2018-190
Liu, J.T., Wang, Y.H., Yang, R.J., Hsu, R.T., Kao, S.J., Lin, H.L. and Kuo, F.H. 2012. Cyclone-induced hyperpycnal turbidity currents in a submarine canyon. Journal of Geophysical Research: Oceans, 117, https://doi. org/10.1029/2011JC007630

Maier, K.L., Gales, J. et al. 2019a. Linking direct measurements of turbidity currents to submarine canyon-floor deposits. Frontiers in Earth Science, 7, 144, https:// doi.org/10.3389/feart.2019.00144

Maier, K.L., Rosenberger, K. et al. 2019b. Sediment and organic carbon transport and deposition driven by internal tides along Monterey Canyon, offshore California. Deep Sea Research Part I: Oceanographic Research Papers, 153, 103108, https://doi.org/10.1016/j.dsr. 2019.103108

Martín, J., Palanques, A., Vitorino, J., Oliveira, A. and De Stigter, H.C. 2011. Near-bottom particulate matter dynamics in the Nazaré submarine canyon under calm and stormy conditions. Deep Sea Research Part II: Topical Studies in Oceanography, 58, 2388-2400, https://doi.org/10.1016/j.dsr2.2011.04.004

Martín, J., Puig, P., Palanques, A. and Ribó, M. 2014. Trawling-induced daily sediment resuspension in the flank of a Mediterranean submarine canyon. Deep Sea Research Part II: Topical Studies in Oceanography, 104, 174-183, https://doi.org/10.1016/j.dsr2.2013. 05.036

McCave, I.N., Thornalley, D.J.R. and Hall, I.R. 2017. Relation of sortable silt grain-size to deep-sea current speeds: calibration of the 'Mud Current Meter'. Deep Sea Research Part I: Oceanographic Research Papers, 127, 1-12, https://doi.org/10.1016/j.dsr. 2017.07.003

Miramontes, E., Penven, P. et al. 2019. The influence of bottom currents on the Zambezi Valley morphology (Mozambique Channel, SW Indian Ocean): in situ current observations and hydrodynamic modelling. Marine Geology, 410, 42-55, https://doi.org/10.1016/j.mar geo.2019.01.002

Mulder, T., Savoye, B. and Syvitski, J.P.M. 1997. Numerical modelling of a mid-sized gravity flow: the 1979 Nice turbidity current (dynamics, processes, sediment budget and seafloor impact). Sedimentology, 44, 305-326, https://doi.org/10.1111/j.1365-3091.1997. tb01526.x

Mulder, T., Zaragosi, S. et al. 2012. Present deepsubmarine canyons activity in the Bay of Biscay (NE Atlantic). Marine Geology, 295, 113-127, https://doi. org/10.1016/j.margeo.2011.12.005

Normandeau, A., Bourgault, D., Neumeier, U., Lajeunesse, P., St-Onge, G., Gostiaux, L. and Chavanne, C. $2019 a$. Storm-induced turbidity currents on a sediment-starved shelf: insight from direct monitoring and repeat seabed mapping of upslope migrating bedforms. Sedimentology, 67, 1045-1058, https://doi.org/10.1111/sed. 12673

Normandeau, A., Campbell, D.C. and Cartigny, M.J. $2019 \mathrm{~b}$. The influence of turbidity currents and contour currents on the distribution of deep-water sediment waves offshore eastern Canada. Sedimentology, 66, 1746-1767, https://doi.org/10.1111/sed.12557

Normark, W.R., Carlson, P.R., Chan, M.A. and Archer, A.W. 2003. Giant submarine canyons: is size any clue to their importance in the rock record? Geological 
Society of America Special Papers, 370, 175-190, https://doi.org/10.1130/0-8137-2370-1.175.

Parsons, D.R., Best, J.L., Lane, S.N., Orfeo, O., Hardy, R.J. and Kostaschuk, R. 2007. Form roughness and the absence of secondary flow in a large confluence-diffluence, Rio Paraná, Argentina. Earth Surface Processes and Landforms, 32, 155-162, https://doi.org/10. 1002/esp.1457

Parsons, D.R., Peakall, J., Aksu, A.E., Flood, R.D., Hiscott, R.N., Beşiktepe, Ş. and Mouland, D. 2010. Gravitydriven flow in a submarine channel bend: direct field evidence of helical flow reversal. Geology, 38, 1063-1066, https://doi.org/10.1130/G31121.1

Paull, C.K., Ussler, W., Greene, H.G., Keaten, R., Mitts, P. and Barry, J. 2002. Caught in the act: the 20 December 2001 gravity flow event in Monterey Canyon. GeoMarine Letters, 22, 227-232, https://doi.org/10. 1007/s00367-003-0117-2

Paull, C.K., Mitts, P., Ussler, W., III, Keaten, R. and Greene, H.G. 2005. Trail of sand in upper Monterey Canyon: offshore California. Geological Society of America Bulletin, 117, 1134-1145, https://doi.org/ 10.1130/B25390.1

Paull, C.K., Ussler, W., III et al. 2010. Origins of large crescent-shaped bedforms within the axial channel of Monterey Canyon, offshore California. Geosphere, 6, 755-774, https://doi.org/10.1130/GES00527.1

Paull, C.K., Talling, P.J. et al. 2018. Powerful turbidity currents driven by dense basal layers. Nature Coтmunications, 9, 4114, https://doi.org/10.1038/s41467018-06254-6

Piper, D.J., Shor, A.N. and Hughes Clarke, J.E. 1988. The 1929 Grand Banks earthquake, slump and turbidity current. GSA Special Papers, 229, https://doi.org/10. 1130/SPE229-p77

Pohl, F., Eggenhuisen, J.T., Kane, I.A. and Clare, M.A. 2020. Transport and burial of microplastics in deepmarine sediments by turbidity currents. Environmental Science \& Technology, 54, 4180-4189, https://doi. org/10.1021/acs.est.9b07527

Pope, E.L., Talling, P.J., Carter, L., Clare, M.A. and Hunt, J.E. 2017. Damaging sediment density flows triggered by tropical cyclones. Earth and Planetary Science Letters, 458, 161-169, https://doi.org/10.1016/j.epsl. 2016.10.046

Prior, D.B., Bornhold, B.D., Wiseman, W.J. and Lowe, D.R. 1987. Turbidity current activity in a British Columbia fjord. Science, 237, 1330-1333, https:// doi.org/10.1126/science.237.4820.1330

Puig, P., Ogston, A.S., Mullenbach, B.L., Nittrouer, C.A., Parsons, J.D. and Sternberg, R.W. 2004. Storm-induced sediment gravity flows at the head of the Eel submarine canyon, northern California margin. Journal of Geophysical Research: Oceans, 109, https://doi.org/10. 1029/2003JC001918

Puig, P., Canals, M. et al. 2012. Ploughing the deep sea floor. Nature, 489, 286, https://doi.org/10.1038/ nature 11410

Puig, P., Palanques, A. and Martín, J. 2014. Contemporary sediment-transport processes in submarine canyons. Annual Review of Marine Science, 6, 53-77, https:// doi.org/10.1146/annurev-marine-010213-135037

Randolph, M.F. and White, D.J. 2012. Interaction forces between pipelines and submarine slides - A geotechnical viewpoint. Ocean Engineering, 48, 32 37, https://doi.org/10.1016/j.oceaneng.2012.03.014

Ribó, M., Puig, P. and van Haren, H. 2015. Hydrodynamics over the Gulf of Valencia continental slope and their role in sediment transport. Deep Sea Research Part I: Oceanographic Research Papers, 95, 54-66, https:// doi.org/10.1016/j.dsr.2014.10.004

Ross, C.B., Gardner, W.D., Richardson, M.J. and Asper, V.L. 2009. Currents and sediment transport in the Mississippi Canyon and effects of Hurricane Georges. Continental Shelf Research, 29, 1384-1396, https://doi. org/10.1016/j.csr.2009.03.002

Ryan, W.B.F. and Heezen, B.C. 1965. Ionian Sea submarine canyons and the 1908 Messina turbidity current. Geological Society of America Bulletin, 76, 915-932, https://doi.org/10.1130/0016-7606(1965)76[915:ISS CAT]2.0.CO;2

Sequeiros, O.E., Pittaluga, M.B. et al. 2019. How typhoons trigger turbidity currents in submarine canyons. Scientific Reports, 9, https://doi.org/10.1038/s41598-01945615-Z

Shepard, F.P. 1954. High-velocity turbidity currents, a discussion. Proceedings of the Royal Society of London, Series A. Mathematical and Physical Sciences, 222, 323-326.

Shepard, F.P. and Marshall, N.F. 1973. Storm-generated current in La Jolla Submarine Canyon, California. Marine Geology, 15, M19-M24, https://doi.org/10. 1016/0025-3227(73)90018-2

Shepard, F.P., McLoughlin, P.A., Marshall, N.F. and Sullivan, G.G. 1977. Current-meter recordings of low-speed turbidity currents. Geology, 5, 297-301, https://doi. org/10.1130/0091-7613(1977)5<297:CROLTC >2.0. $\mathrm{CO} ; 2$

Shih, H.H. 2012. Real-time current and wave measurements in ports and harbors using ADCP. In: 2012 Oceans-Yeosu. IEEE, 1-8.

Sumner, E.J., Peakall, J. et al. 2013. First direct measurements of hydraulic jumps in an active submarine density current. Geophysical Research Letters, 40, 5904-5908, https:// doi.org/10.1002/2013GL05 7862

Syahnur, Y. and Jaya, K.A. 2016. Geomatics best practices in Saka Indonesia Pangkah Limited (Case Study: Ujung Pangkah Pipeline Integrity). 2015 Indonesian Petroleum Association Convention, Jakarta, Indonesia.

Symons, W.O., Sumner, E.J. et al. 2017. A new model for turbidity current behavior based on integration of flow monitoring and precision coring in a submarine canyon. Geology, 45, 367-370, https://doi.org/10.1130/ G38764.1

Syvitski, J.P. and Hein, F.J. 1991. Sedimentology of an Arctic Basin: Itirbilung Fiord, Baffin Island, Northwest Territories. Geological Survey of Canada, Paper 91-11.

Talling, P.J., Paull, C.K. and Piper, D.J. 2013. How are subaqueous sediment density flows triggered, what is their internal structure and how does it evolve? Direct observations from monitoring of active flows. Earth-Science Reviews, 125, 244-287, https://doi.org/10.1016/j.ear scirev.2013.07.005

Thorne, P.D. and Hanes, D.M. 2002. A review of acoustic measurement of small-scale sediment processes. Continental Shelf Research, 22, 603-632, https://doi.org/ 10.1016/S0278-4343(01)00101-7 
Urlaub, M., Petersen, F. et al. 2018. Gravitational collapse of Mount Etna's southeastern flank. Science Advances, 4, eaat9700, https://doi.org/10.1126/sciadv.aat9700

Vangriesheim, A., Khripounoff, A. and Crassous, P. 2009. Turbidity events observed in situ along the Congo submarine channel. Deep Sea Research Part II: Topical Studies in Oceanography, 56, 2208-2222, https:// doi.org/10.1016/j.dsr2.2009.04.004

Vendettuoli, D., Clare, M.A. et al. 2019. Daily bathymetric surveys document how stratigraphy is built and its extreme incompleteness in submarine channels. Earth and Planetary Science Letters, 515, 231-247, https:// doi.org/10.1016/j.eps1.2019.03.033

Wynn, R.B., Huvenne, V.A. et al. 2014. Autonomous Underwater Vehicles (AUVs): their past, present and future contributions to the advancement of marine geoscience. Marine Geology, 352, 451-468, https://doi. org/10.1016/j.margeo.2014.03.012

$\mathrm{Xu}$, J.P. 2011. Measuring currents in submarine canyons: Technological and scientific progress in the past 30 years. Geosphere, 7, 868-876, https://doi.org/10. 1130/GES00640.1

Xu, J.P. and Noble, M.A. 2009. Currents in Monterey submarine canyon. Journal of Geophysical Research: Oceans, 114, https://doi.org/10.1029/2008JC004992

Xu, J.P., Noble, M.A. and Rosenfeld, L.K. 2004. In-situ measurements of velocity structure within turbidity currents. Geophysical Research Letters, 31, https:// doi.org/10.1029/2004GL019718

Xu, J.P., Swarzenski, P.W., Noble, M. and Li, A.C. 2010. Event-driven sediment flux in Hueneme and Mugu submarine canyons, southern California. Marine Geology, 269, 74-88, https://doi.org/10.1016/j.margeo.2009. 12.007

Xu, J.P., Barry, J.P. and Paull, C.K. 2013. Small-scale turbidity currents in a big submarine canyon. Geology, 41, 143-146, https://doi.org/10.1130/G33727.1

Xu, J.P., Sequeiros, O.E. and Noble, M.A. 2014. Sediment concentrations, flow conditions, and downstream evolution of two turbidity currents, Monterey Canyon, USA. Deep Sea Research Part I: Oceanographic Research Papers, 89, 11-34, https://doi.org/10. 1016/j.dsr.2014.04.001

Yergin, D. 2006. Ensuring energy security. Foreign Affairs, 85, 69-82, https://doi.org/10.2307/20031912

Zeng, J., Lowe, D.R., Prior, D.B., Wiseman, W.J., Jr and Bornhold, B.D. 1991. Flow properties of turbidity currents in Bute Inlet, British Columbia. Sedimentology, 38, 975-996, https://doi.org/10.1111/j.1365-3091. 1991.tb00367.x

Zhang, Y., Liu, Z. et al. 2018. Long-term in situ observations on typhoon-triggered turbidity currents in the deep sea. Geology, 46, 675-678, https://doi.org/10. 1130/G45178.1 